\title{
Reciprocity matters: Idiosyncratic deals to shape the psychological contract and foster employee engagement in times of austerity
}

\author{
Amanda S. Davis ${ }^{1}$ () | Beatrice I. J. M. Van der Heijden $2,3,4,5$
}

${ }^{1}$ Business School, Manchester Metropolitan University, Manchester, UK

${ }^{2}$ Institute for Management Research, Department SHRM, Radboud University, Nijmegen, The Netherlands

${ }^{3}$ Open University of the Netherlands, Heerlen, The Netherlands

${ }^{4}$ Kingston Business School, Kingston University, Kingston-Upon-Thames, UK

${ }^{5}$ Hubei University, Wuhan, China

Correspondence

Amanda S. Davis, Business School, Manchester Metropolitan University, All Saints Campus, Oxford Road, Manchester M15 6BH, UK.

Email: asd51987@aol.com
Following the 2007/2008 global financial crisis, the UK public sector has experienced major funding cuts resulting in staffing reductions and a dilution in the employment deal. Consequently, the aim of this study is to understand how i-deals, which are unique conditions of employment negotiated between an individual and their employer (Rousseau, 2005), may be used to accept a new psychological contract and foster employee engagement during austerity. Four qualitative team case studies were conducted comprising senior, middle-line, and first-line managers, and either professional or nonprofessional employees, within one English local authority (LA). Methods included $29 \times$ one-to-one and three focus group semistructured interviews incorporating the critical incident technique. By examining i-deals through the lens of social exchange theory (Blau, 1964), this research demonstrates the role of reciprocity in the form of $\mathrm{i}$-deals to accept the new psychological contract and foster engagement. Here, for some employees, once concrete and universal resources were available to a certain level (e.g., pay), the difference (e.g., universal resources such as a pay rise, external training) was substituted by more particularistic resources (e.g., flexibility and developmental i-deals) herewith extending Foa and Foa's (1976, 1980, and 2012) resource theory. Furthermore, resultant economic or social exchange may be due to the individual attribution of why the i-deal was agreed, rather than the i-deal content. Finally, when i-deals are denied, action to lower the risk of psychological contract breach is advised.

\section{KEYWORDS}

austerity, career development, employee engagement, I-deals, idiosyncratic deals, psychological contract, public sector, reciprocity, work-life balance 


\section{1 | INTRODUCTION}

Following the 2007/2008 global financial crisis and subsequent recession, many Western countries are coping with austerity measures to reduce public spending (Cepiku, Mussari, \& Giordano, 2016; Conway, Kiefer, Hartley, \& Briner, 2014; Kickert, 2012). In relation to English local authorities (LAs), which are public sector organizations that are run by locally elected councillors and provide a diverse range of public services from waste management and recycling to education, this presents an immense challenge given LAs will have had their Central Government funding reduced by $£ 16$ billion between 2010 and 2020 (Local Government Association, 2017). Consequently, LAs have been transforming their services to enable them to continue to meet their statutory duties within these funding cuts (Bach, 2011). Such reorganization has created job insecurity for LA employees due to organizational restructures, redundancies (although redeployment will normally be considered-Local Government Association, 2013), and reduced pay, benefits, and terms and conditions (CIPD/PPMA, 2012; Francis, Ramdhony, Reddington, \& Staines, 2013). However, these cost reduction methods are insufficient to meet the budget challenge (Bach, 2011). Consequently, both the previous UK Labour and Coalition Governments in power at the time of the data collection encouraged LAs (and all sectors) to deal with this radical change by leadership and employee engagement (Bach, 2011; Department for Business, Innovation and Skills, 2011) as per the MacLeod and Clarke (2009) report. Despite austerity reducing the number of levers available to managers to foster engagement, there has been minimal attention to the impact this has had on the employment relationship (Bach, 2011; Francis et al., 2013), or on the process of fostering employee engagement (Reissner \& Pagan, 2013) and subsequent employee attitudes and behaviors (Kiefer, Hartley, Conway, \& Briner, 2014; Van der Voet \& Vermeeren, 2016). That said, a 2-year pay rise has been agreed from April 2018 (Unison, 2018) demonstrating the recent political (pressure) commitment to increase spending (HM Treasury, 2018) following the UK General Election in 2017 where the Government lost its majority. However, the unknown challenges of Brexit and increase in service demands from the aging population suggest that budget pressures will continue (Inman, 2018) making it important to learn from the past to prepare for the future.

The first aim of this article is to contribute to this timely discussion by examining how idiosyncratic deals, also known as $\mathrm{i}$-deals, which are unique conditions of employment negotiated between an individual worker and their employer (Rousseau, 2005), may be used to help employees accept the changing psychological contract (Hiltrop, 1995), in particular the demise of the public sector's notion of a "job for life," along with the diluted employment deal in terms of pay freezes and reductions in benefits (including external training), terms and conditions (CIPD/PPMA, 2012). Although this has been examined previously within LAs (e.g., Coyle-Shapiro \& Kessler, 2000), the austerity context makes it relevant again.

Second, we aim to better understand how i-deals may be used to foster employee engagement given their potential to offer alternative low-cost reciprocations (Hornung, Rousseau, \& Glaser, 2008; Rousseau, 2005; Vidyarthi, Chaudhry, Anand, \& Liden, 2014). This is likely to be of interest to HRD practitioners and scholars, because learning and development tends to reduce during downsizing (Wilkinson, 2005). Withdrawing such quality-related human resource (HR) practices is likely to have an adverse effect on employee perceptions of organizational ethics and work attitudes (Valentine, Hollingworth, \& Francis, 2013), which may lead to disengagement. Furthermore, by better understanding the meanings of these reciprocations, we build on the extant research, which recognizes the importance of the line manager's role in fostering employee engagement (Alfes, Truss, Soane, Rees, \& Gatenby, 2010; Lewis, Donaldson-Feilder, \& Tharani, 2012). To the best of our knowledge, up until now i-deals have not been studied in relation to a context of austerity and employee engagement. In summary, this article examines empirically through the lens of social exchange theory (SET) (Blau, 1964) how ideals may be used to encourage the acceptance of a new psychological contract and foster employee engagement. 


\section{2 | THEORETICAL FRAMEWORK}

I-deals will now be defined and their relationship with the psychological contract explained. Then, employee engagement will be introduced as the intended outcome from i-deals.

\subsection{1 | I-deals and the psychological contract}

Rousseau (2005) explained that "i-deals are special conditions of employment negotiated between an individual worker and his or her employer" (p. 7) that benefit both individuals and the organization. As such, their scope can vary from a single feature such as working on a different task/project to coworkers, to making every aspect of the employment deal unique (Rousseau, 2005; Vidyarthi et al., 2014). That said, i-deals are occupational-specific (Rosen, Slater, Chang, \& Johnson, 2013) as some benefits are not available for some jobs, such as location/distancing flexibility for frontline staff. I-deals are also used in some bureaucratic organizations where employment practices are normally standardized (Hornung et al., 2008), perhaps due to the increasing individualization of the employment relationship, coupled with the drive to be leaner and agile (Bach, 2011; CIPD/PPMA, 2012). I-deals may be ex ante, which are agreed during hiring, or ex post which are made during employment (Anand, Vidyarthi, Liden, \& Rousseau, 2010). Ex post $i$-deals are investigated here to understand the impact on the psychological contract and on fostering engagement in austerity.

In order for a change to an employment term and condition to be an i-deal, it must meet four criteria (Rousseau, Ho, \& Greenberg, 2006). It must be individually negotiated and authorized, have mutual benefits to the employee and employer, be varied in scope and be distinct (heterogeneity of treatment of employees doing similar jobs). Despite this, the bounds of the i-deal's definition are still vague. For example, if an employee on fixed hours requests to finish work early one day, is that a micro i-deal? Such discretionary "single short-term requests" may be more appropriately classed as a "favor" to the employee, given the "short-term nature" and lack of mutual benefits. Managers may grant such favors to demonstrate commitment to the relationship (Blau, 1964), which is important in the fostering of engagement, as are other interventions (e.g., leadership style). However, this article just examines social exchange via i-deals in order to focus the inquiry. Nevertheless, the distinction between favors and i-deals demonstrates that the i-deals' definition may benefit from incorporating some element of "duration/longevity" to preclude such "single short-term" requests from the i-deals' discourse.

I-deals can comprise many forms and common small i-deals discussed in the literature that are related to this study include developmental/task i-deals and flexibility i-deals (e.g., Hornung et al., 2008; Rosen et al., 2013). Developmental/task i-deals are particularly interesting given their scope to provide, informal workplace learning. This is because developmental/task i-deals can provide planned (Lohman, 2006) and experiential (Cunningham \& Hillier, 2013) learning that occurs outside of the classroom and is requested by the individual (Crouse, Doyle, \& Young, 2011) through the i-deal negotiation, although it can be facilitated by the supervisor and context (Cunningham \& Hillier, 2013). It can also be enhanced with other development techniques such as coaching and mentoring. Not all task $\mathrm{i}$-deals are developmental though as some may just provide variety with no further learning.

I-deal theory postulates that i-deal recipients will reciprocate with constructive behaviors (Anand et al., 2010; Hornung et al., 2008; Vidyarthi et al., 2014). The function of reciprocity is explained by SET (Blau, 1964) that considers that people are motivated by the expectation of receiving benefits from another party in exchange for something. Such an exchange is underpinned by the norm of reciprocity (Gouldner, 1960) that obligates individuals to respond positively once they have received the benefit (Blau, 1964; Gouldner, 1960). Receipt of such inducements may develop expectations of receiving more inducements through social exchange, thus resulting in an ongoing reciprocation. Moreover, the authorizing party may also gain credibility due to consideration of their employees' needs (Liao, Wayne, \& Rousseau, 2014). That said, the exchange process is nonspecific with the type/timing/amount of such a return (Blau, 1964), and the mutual benefits may be received at different times (Liao et al., 2014). As such, organizations typically do not bargain the exact nature of reciprocity that they expect in return (Vidyarthi et al., 
2014) relying on the employee's sense of obligation (Blau, 1964). Furthermore, not everyone may be motivated by social exchange. People cannot be obliged to reciprocate with more cognitive/affective/behavioral effort, as that is part of their discretionary behavior (Purcell, 2012). Reciprocity is not guaranteed although it is more likely among those with a strong exchange orientation (Cropanzano \& Mitchell, 2005). Consequently, while SET does not explain employee engagement in its entirety, it does help understand the effect of managerial actions in the process of fostering engagement (Shuck, Twyford, Reio, \& Shuck, 2014).

I-deals are related to, yet different from, psychological contracts (Anand et al., 2010; Liao et al., 2014) that are employer/employee expectations (Argyris, 1960; Schein, 1980) or promises/obligations (Guest \& Conway, 2002) toward each other, and therefore, based on individual perceptions (Rousseau, 1989). Whereas i-deals are individually negotiated actual treatment/resources that other coworkers in the same/similar roles do not receive (Rousseau, 2005), and yet consider fair (Rousseau et al., 2006). The pursuit of an i-deal may depend on an employee's psychological contract in whether he/she believes that the organization is obliged to offer something in return for their efforts (Liao et al., 2014; Rousseau, 2005). The i-deal will also shape the psychological contract that may strengthen the employment relationship (Bal \& Rousseau, 2016) and foster employee engagement discussed next.

\subsection{2 | Employee engagement}

There is no universally agreed academic definition of employee engagement, but many researchers (e.g., Rich, Lepine, \& Crawford, 2010; Shuck \& Wollard, 2010) refer back to Kahn's (1990) definition: “... in engagement people employ and express themselves physically, cognitively and emotionally during role performances" (p. 694). In other words, workers choose how much effort they exert in their job (Kahn, 1990). That said, engagement may start with effort, but it is more than effort. Rather than just following predetermined routines, the engaged employee will care about their work, focus and apply their ideas, problem solving and feelings, and voice their opinion to do the best they can at work (Kahn, 2010).

Referring to the employee engagement definition, Shuck and Reio (2011) explain that cognitive engagement is how an employee understands their job, organization, and culture. This links to the "strategic narrative" driver (MacLeod \& Clarke, 2009) where an individual understands how their job contributes to organizational goals, leading to the individual asking themselves "does it [their work] matter?" (Kahn, 2010, p. 22). Saks (2006) and Shuck, Ghosh, Zigarmi, and Nimon (2012) expand on this by explaining that it also involves the focus they give to their work, and in some cases being innovative/creative. It is this innovation and aspirational goal of smarter working that the Coalition Government desired at the beginning of austerity, hence their support to the "Engage for Success" movement (Department for Business, Innovation and Skills, 2011).

Emotional engagement is the bond an individual feels toward his/her work such as pride and belief (Shuck \& Reio, 2011). These positive emotions can broaden an employee's thinking and innovativeness (Fredrickson, 2001). Consequently, this triggers action from the cognitive appraisal of the situation (Shuck \& Herd, 2012), which is similar to Amabile and Kramer's (2007) inner work life process motivation model, which also shows how emotion, cognition, and perception are so closely linked and how this impacts peoples' performance.

Physical engagement has been operationalized as effort, performance, or productivity (Shuck \& Reio, 2011) and is sometimes referred to as behavioral engagement (Saks, 2006; Shuck \& Reio, 2011). However, given the risk of overlapping with other constructs and their associated ethical implications such as work intensification, other authors (such as Alfes et al., 2010; Soane et al., 2012) refer to it as social engagement to highlight how engaged individuals interact with coworkers to propose and implement new ideas. As such, behavioral and social engagement is a manifestation of cognitive and emotional engagement (Shuck et al., 2014; Shuck \& Herd, 2012; Shuck \& Reio, 2011), as it is "how individuals employ themselves in the performance of their job" (Saks, 2006, p. 602) suggesting it can be observed. This stems from the employees' continuous assessment of work-related factors, directing them to either pull toward or away from their work/stakeholders (Alagaraja \& Shuck, 2015; Shuck, Rocco, \& Albornoz, 2011). The activation here is what makes engagement different to other related constructs such as job involvement, 
commitment, and satisfaction, as engagement is the point that work is underway (Shuck et al., 2012). It is also different to flow that is a momentary occurrence lasting up to $1 \mathrm{hr}$ (Bakker, 2011) where an employee is so absorbed in their work, with clarity of thought, that time seems to fly by (Csikszentmihalyi, 1990), whereas, engagement is longer-term (Schaufeli, Salanova, González-Romá, \& Bakker, 2002; Shuck \& Wollard, 2010).

In addition, engagement refers to an employee's formal work role rather than their extra-role behavior (Saks, 2006). As Newman and Harrison (2008) state, employee engagement is when an employee is considered to be "in gear" (p. 35). This makes it relevant to this particular study as extra-role behavior may be restricted due to the scale of downsizing (Kiefer et al., 2014).

That said, engagement levels can vary and people may engage to their team (Saks \& Gruman, 2014), line manager, profession, task (Baron, 2013), customer (Gourlay et al., 2012) job, and/or organization (Saks, 2006; Saks \& Gruman, 2014). Consequently, engagement terms differ and when used appropriately, the terms signify that people may engage with different elements of organizational life. For example, work engagement is engagement to the work, while employee engagement has been defined both as engagement to the organization (Schaufeli, 2014; Truss, 2014), and alternatively as the intensity and direction of cognitive, emotional, and behavioral energy of employees (Shuck, Osam, Zigarmi, \& Nimon, 2017). On the other hand, Kahn $(1990,1992,2010)$ deliberately focused on personal engagement, rather than on work or employee engagement, to enable an exploration of peoples' experiences (Kahn, 1992) and consider how much of themselves people bring to their work roles (Kahn \& Heaphy, 2014). This demonstrates the individual nature of the engagement phenomenon and the personal agency employees apply to their work (Cole, Walter, Bedeian, \& O'Boyle, 2012; Rich et al., 2010).

Academic definitions of engagement are also divided on whether employee engagement is a trait (Macey \& Schneider, 2008-although they consider engagement is a trait, state, and behavioral package), psychological state (Schaufeli et al., 2002), or a behavior (Alfes et al., 2010; Saks, 2006). The current HRD literature discussed here views Kahn's (1990) engagement definition as a process motivational state (Shuck et al., 2017). This view considers the physical/behavioral dimension of Kahn's (1990) definition to consist of "behavioral energy" and "intention" (p. 269) following the dynamic cognitive and emotional appraisal of work factors. Consequently, they consider that engagement cannot be seen but it is experienced and this then informs the direction and intensity of employees' energies (Alagaraja \& Shuck, 2015). As such, this view considers that the "active, full role performance" within Kahn's (1990, p. 700) definition is an outcome of engagement. That said, given Kahn's (1990, p. 700) focus on "active, full role performance" and the examples he provides, which include exercising employee voice, problem-solving and taking corrective action, we agree with Guest (2014) in that Kahn's (1990) definition is a behavioral one, and we will use that within this study. This is because behavioral engagement is more able to incorporate context (Purcell, 2014), which is critical to this study, and is more likely to be of interest to organizations (Newman \& Harrison, 2008; Saks, 2008). It also enables us to incorporate the views of both line managers and employees given behavioral engagement is easier to assess (e.g., by line manager observation)-being a significant strength of the study rather than relying on employee self-report alone. In particular, thinking about how to do the job better (cognitive) and sharing these ideas with coworkers/managers (behavioral/social) are pertinent to this study given the need to still meet statutory responsibilities within the funding and staffing reductions caused by the austerity measures. Therefore, the following research questions are central to this contribution:

1. To explore how i-deals may be used to help employees accept the changing psychological contract, given the demise of the public sector's notion of a "job for life," along with the diluted employment deal in terms of pay freezes and reductions in benefits (including external training), terms and conditions;

2. To better understand how i-deals may be used to foster employee engagement within an austerity context given their potential to offer low-cost reciprocations.

The methodology to investigate these research questions will now be explained. 


\section{3 | METHODOLOGY}

\subsubsection{Sample and procedure}

This study was conducted using four cross-sectional qualitative case studies within one English LA employing just under 5,000 full time equivalent (FTE) employees. The LA is publically funded through Government grants, Council tax, and Business rates, and provides a wide range of services to the community such as refuse collection and waste management, street lighting, libraries, social care, housing, and education. The organization has downsized by $21.3 \%$ since 2011 reducing from 5944.91 FTE in 2011, to 4678.87 FTE in 2015. Employees' pay was frozen from $2010 / 2011$ to $2012 / 2013$ inclusive, and Directors' pay has been frozen since 2009. At the time of data collection (July 2013 to August 2014), consultations were ongoing to reduce terms/conditions and agree the 2013/2014 pay award.

Multiple case studies were chosen to enable an examination of how the context (Kahn, 1992) of austerity leads to the negotiation of $\mathrm{i}$-deals (Hornung et al., 2008). Setting this within a constructionist/interpretivist paradigm (Blaikie, 2007) and bounding the cases by the team showed how engagement can be fostered by line managers given the reduction of levers available to them due to austerity, and how these efforts are experienced by employees and the impact on their psychological contract. As this involved an examination at the micro (i.e., team) level, multiple case studies were preferred to a single case study embedded design (where the four teams would be considered as subunits of the single LA case study) as the research questions did not require an examination at the larger unit of analysis (i.e., the LA), which was considered as the internal context (Yin, 2009). It also ensured that a reasonable proportion of individuals were sampled in relation to the team size (Purcell, Kinnie, Hutchinson, Rayton, \& Swart, 2003).

Theoretical sampling of the LA was problematic as little is known academically about the "lived experiences of engagement" (Truss, Shantz, Soane, Alfes, \& Delbridge, 2013). Consequently, purposive sampling was used to select a LA that was deliberately seeking to engage their employees, obtained from a previous quantitative survey conducted by the first author. Teams were selected by theoretical sampling to see if there was a difference in i-deals between professionals, nonprofessionals, and managers given their likely different orientations to work (Goldthorpe, Lockwood, Bechofer, \& Platt, 1968). Professionals were defined as those who needed externally certified education/ training to do their job (Purcell et al., 2003). Nonprofessionals were included as well because much of the literature suggests that meaningfulness, development, and involvement foster engagement (e.g., Alfes et al., 2010), so it appears that employees with an instrumental orientation, who may not be interested in pursuing development and involvement activities, are excluded from this discourse. Employee respondents were selected by their managers as time away from their normal duties to participate in this study needed to be authorized. All 45 participants had permanent full/part-time contracts, and were employed with the LA for at least 1 year. Thirty-two participants were female and 13 participants were male (see Appendix A). Participation was voluntary, individual written consent was gained, and anonymity promised.

Methods used were individual semistructured interviews with all levels of line managers within each of the four teams (three senior, five middle-line, and five first-line managers; Mintzberg, 1983) and 16 employees using the critical incident technique (Flanagan, 1954) with a phenomenological approach (Chell, 2004). In addition, three employee focus group interviews with a total of 16 participants were held to see if there were any visible coworker conflicts from the i-deals discussed. In all cases, managers were interviewed prior to employees to ensure that employee confidentiality was not inadvertently breached. For this reason, it was also decided not to interview managers for a second time after interviewing employees, because while this would have enhanced credibility further (Guba \& Lincoln, 1994), it would have been at an unacceptable risk to the employee participants. Similarly, it was decided not to report participant gender and job title for each interview quote, despite the possibility of this revealing gender differences in terms of the meaningfulness people seek from work, or the psychological availability (Kahn, 1990) they bring to their work, to prevent inadvertently revealing participants' identity. Furthermore, the research design and sample size were not appropriate to produce such generalizations. 
The semistructured nature of the interview questions meant that interviews ranged from 33 to 114 min, enabling participants to raise salient issues not originally anticipated by us. Interview questions asked participants how their manager fosters their engagement (explained as how he/she gets the best from them, helps them focus on their work, care about their work, and enables them to share and implement ideas/improvements with others). Questions also asked respondents to recall a time (i.e., a critical incident-Flanagan, 1954) when they negotiated aspects to their employment that were not available to their team peers (the interview questions are available from the first author upon request). Although the critical incident technique is normally criticized for its problems with recall bias (Flanagan, 1954), this was not problematic for this study as it is these distorted views that inform employees' perceptions and lead to their behavioral engagement or disengagement. It also avoided the need to estimate the time duration of the "lag" effect (Khilji \& Wang, 2006) where any number of factors could also affect engagement. From the 45 participants, 10 reported that they had, or tried to gain, or knew others who had an i-deal, demonstrating the idiosyncratic nature of the $\mathrm{i}$-deal as not all employees had one.

The employee interview focus groups enabled the interviewees to question each other's views and justify points. Groupthink, where the desire for unanimity results in the group agreeing with each other rather than appraising the points raised (Janis, 1972), was reduced additionally by ensuring that the participants were nonmanagement employees of a similar level/status to avoid/reduce pressure to contribute "acceptable views." Focus group participants were different to those interviewed on a one-to-one basis to prevent/reduce contamination.

All interviews (both individual and focus group) were recorded and transcribed verbatim. Interviewees were asked to check the interview transcripts (respondent validation) to contribute to credibility and trustworthiness. Four participants provided additional information by email and one participant requested an additional interview providing an opportunity for "collaboration and reflexive elaboration" (Tracy, 2010, p. 8). This was particularly useful for the interview focus group participants given some employees may have been reluctant to discuss their i-deal with coworkers due to the insecure job climate.

\subsection{2 | Analysis}

NVivo software enabled the interview transcripts to be grouped/coded into themes. This was achieved using template analysis which "is a style of thematic analysis that balances a relatively high degree of structure in the process of analysing textual data with the flexibility to adapt it to the needs of a particular study" (King, 2012, p. 426). Consequently, it is appropriate for a phenomenological and interpretivist epistemology (among others), it is able to analyze multiple perspectives and large quantities of data (both within and across cases), it permits a priori coding, and is systematic. In addition, flexibility is gained as it does not insist on a fixed number of levels of coding hierarchy, enabling more themes to be identified and coded in the richest data (King, 2012), which was useful when coding i-deals and their features.

All four case studies were initially analyzed individually to increase familiarity, identify within-case patterns, and make comparisons with the literature to understand meaning, highlight similarities/contradictions, and consider reasons for differences (Eisenhardt, 1989). The eight themes initially coded were mainly taken from Purcell and Hutchinson's (2007) People Management-Performance Causal Chain model. These provided the highest level coding intending to highlight the whole process from management actions planned and taken in the fostering of employee engagement, and employees' perceptions, and subsequent attitudes and behaviors this generated. The lower-level codes were developed through an iterative process of reading through the transcripts and inductively noting emerging themes that illuminated these experiences in more depth (Poppleton, Briner, \& Kiefer, 2008) such as contextual information as well as the new reciprocations negotiated and desired through different i-deals. Consequently, the coding process was repeated numerous times given the coding template increased with each interview transcript (the first and final code list is available from the first author upon request). This created a need to revisit previously coded transcripts to reapply the new codes where appropriate. After all transcripts were coded, the employee data were compared with the line managers' data to contribute to trustworthiness/credibility (Guba \& Lincoln, 1994). As 
no new codes were created in the third and fourth teams, thus suggesting that the same themes were replicated, further sampling was deemed unnecessary.

After all teams had been analyzed individually, a case-oriented approach (Miles, Huberman, \& Saldaña, 2014) was used to compare the cases systematically in two ways. First, the professional and nonprofessional teams were compared to see if there were any similarities/differences in the type of i-deals requested. Then, agreed and denied i-deals were analyzed to understand the process and impact on the psychological contract. The interpretivist nature of this study meant that the consideration of different perspectives, richness of description, and reflexivity contributed to rigor, which was more important than reliability as that relates more to quantitative studies (King, 2012). The first author's LA background was advantageous here given her understanding of the LA's statutory obligations and austerity constraints. However, it was also problematic due to the risk of bias and temptation to solve organizational problems (Carey, 1994). Field notes of observations/feelings were recorded to help with this and provided support for findings that initially seemed trivial, but gained importance as the analysis developed (Eisenhardt, 1989; Flyvbjerg, 2006).

\section{\begin{tabular}{l|l}
4 & RESULTS
\end{tabular}}

The analysis' outcomes are elaborately summarized in Table 1 and will now be presented:

As regards Research Question 1: To explore how i-deals may shape the psychological contract, despite the employment deal being reduced, the types of $\mathrm{i}$-deals were identified, the process of agreed and denied i-deals was analyzed, and the types of exchange relationship fostered were examined.

\section{1 | Types of I-deals}

Twenty-two percentage of the sample reported on either agreed or denied i-deals demonstrating the idiosyncratic nature of these deals as only some people had one. These may be categorized as employability/career development (task), flexibility, and redeployment (see Table 1). Employability i-deals are task i-deals that provide workplace learning (e.g., job enlargement) to boost a worker's employability making them more effective and valuable to the organization, or increase their labor-market opportunities from their increased skills. Career development i-deals may also be task i-deals that not only boost employability, but also provide workplace learning (e.g., job enrichment such as managing projects) that increases the chances of career progression. Flexibility i-deals are changes to working hours and working patterns, which can enhance the employee's work-life balance. Redeployment i-deals involve employees

TABLE 1 Summary of i-deals

\begin{tabular}{|c|c|c|}
\hline & Agreed i-deals & Denied i-deals \\
\hline Nonprofessionals & $\begin{array}{l}\text { Redeployment: } \\
\text { - Redeployment (Team 3) } \\
\text { (redeployment request form) }\end{array}$ & $\begin{array}{l}\text { Flexibility: } \\
\text { - } \text { Adjustment of part time hours following } \\
\text { organizational restructure (Team 4) } \\
\text { Redeployment: } \\
\text { - } \text { Redeployment (Team 4) (no } \\
\text { redeployment request form) } \\
\text { Employability/career development (task): } \\
\text { - Varied tasks (Team 3) } \\
\text { - Educational support (Team 3) }\end{array}$ \\
\hline Professionals & $\begin{array}{l}\text { Flexibility: } \\
\text { - Condensed working week (Team 1) } \\
\text { Employability/career development (task): } \\
\text { - Project work (Team 1) }\end{array}$ & $\begin{array}{l}\text { Redeployment: } \\
\text { - Redeployment (Team 2) (no } \\
\text { redeployment request form) }\end{array}$ \\
\hline Managers & $\begin{array}{l}\text { Flexibility: } \\
\text { - Adjustment to hours (Team 4) } \\
\text { - Reduction in hours from full time to } \\
\text { half time (Team 1). }\end{array}$ & \\
\hline
\end{tabular}


negotiating alternative employment (including location and/or job/tasks responsibilities) because their existing post is deleted/withdrawn.

Where policies are available to everyone, they will not be considered to be an i-deal because standardized policies are not exceptional (Rousseau, 2005). Although the LA has formal work-life balance (flexibility) and redeployment policies, these are not a right and approval is subject to it meeting business/service needs. Consequently, requests have to be negotiated as demonstrated by one of the line managers who agreed a flexibility i-deal where working hours were reduced by half:

I had to convince them that my staff could be unsupervised when I was not there, that they had no objection to my change and finally that I could still do my job. (First-Line Manager, 50-64 years, Professional Team 1)

It is this individual negotiation coupled with heterogeneous and exceptional outcomes (Rosen et al., 2013; Rousseau, 2005), due to the variation of flexibility and redeployment i-deals that are sought (Anand et al., 2010), which places flexibility and negotiated redeployment back into the i-deals arena.

Both professionals and nonprofessionals tried to gain flexibility and redeployment $\mathrm{i}$-deals. One of the agreed flexibility i-deals was as follows:

And the flexible working can work so that you can drop your children off at school and pick them up. (Employee, 40-49 years, Professional Team 1)

This shows how the flexibility i-deal provides work-life balance, whereas the redeployment i-deal related to negotiating a new location:

And then I came back here, because this was better for me, financially, family, medically, children. But it was on the understanding that I would still do cover at the [named largest site]. (Employee, 25-39 years, Nonprofessional Team 3)

Again, this redeployment i-deal suits the employee's home circumstances, but it was on the agreement that the employee would provide cover at the largest site when necessary, demonstrating the mutual benefits required in ideals.

Employability/career development task i-deals are pursued by some professional staff in the form of project work that offered some on-the-job learning and development, and by nonprofessionals by varied tasks that can provide development and variety:

... it's personal choice. It's whether you want to get involved with something or not. And whether there is development in that for you. (Employee, 40-49 years, Professional Team 1)

Well it's more experience, and a bit more knowledge, doing certain things like [named project], it was good to know, understand how that side of it works. .... Errm, so, I guess for me it's it's I get a buzz because then I get to talk to different people, it's a bit of networking I suppose as I'm getting to know the people in other areas, so for me I kinda get a bit of a satisfaction. (Employee, 40-49 years, NonProfessional Team 3)

The quotes show that the employees did not appear to consider this extra work to be exploitive given they had a choice in doing it. Rather, they appear to value the development opportunities it provides. Of further interest here is that employees have purposefully negotiated these benefits for themselves. The low-cost nature of these benefits may suggest that employees have considered both their needs and the organization's ability to afford such benefits. Consequently, the flexibility i-deal would enhance the individual's work-life balance at very little cost to the 
organization, given it was the responsibility of the individual to propose how his/her workload could be achieved. Similarly, the redeployment i-deal may be low cost given it may just involve a reallocation of staff across available sites. Furthermore, given training budgets have been reduced resulting in limited training provision, mainly restricted to e-learning and mandatory face-to-face training, external training appears to be substituted by developmental/task i-deals that provide some form of development, be that employability or career development. How these substitutions affected the psychological contract will be considered next by analyzing agreed and denied i-deals, followed by the type of exchange fostered.

\subsection{Agreed and denied I-deals' comparison}

To explore the impact on the psychological contract further, the processes involved with agreed and denied i-deals were compared. Agreed i-deals involve individuals putting forward business/service reasons why it would work:

From a domestic point of view it suits me, I've gone to part time-half hours-and that suits me. ... I was not offered any reduction in my workload or the expectations they had of me, nor was I offered job share. It was clear that if I wanted to reduce my hours I had to make the necessary adjustments. (First-Line Manager, 50-64 years, Professional Team 1)

Consequently, in this flexibility i-deal the employee, who was also a first-line manager, explained that identifying the solution to permit the reduction in hours was their responsibility. Although the first-line manager's post was a full-time position, job share was not offered. Rather the first-line manager had to identify how their job could be distributed through the team, ensuring the team was not adversely affected by a $50 \%$ reduction in direct supervision. This enabled the first-line manager's salary to be reduced by $50 \%$, which provided senior management with a $50 \%$ salary saving that could be used to contribute to the budget cuts required in the austerity measures. Consequently, this i-deal led to an outcome that senior management may not have identified, suggesting that engagement in the form of innovative behavior drives i-deals.

Redeployment i-deal negotiations are conducted in a similar way where employees have to convince management of the advantages:

It's got to be like war and peace, hasn't it, basically it's got to be like an essay. (Employee, 25-39 years, Nonprofessional Team 3)

Honestly you felt you were being interviewed all over again. You had to give really good reasons. (Employee, 50-64 years, Nonprofessional Team 3)

Again this demonstrates that the i-deal negotiating process was not easy and that the i-deal had to genuinely provide mutual benefits to the employee and organization. This places significant pressures on employees in identifying the business benefits of their proposed i-deal, which may be particularly difficult for employees that lack the selfconfidence and/or the business knowledge to make a credible request. In some cases, employees are provided with a form to help them articulate their i-deal request:

It's got to be financial, family, children, medical, if it's not one of those, ..., then you won't get your first choice. (Employee, 25-39 years, Nonprofessional Team 3)

Essentially this is an "i-deal request form" that helps employees articulate sufficient business benefits for their proposed i-deal. In addition, this low-cost intervention helps to encourage reasonable proposals with the most chance of success. This reduces employee and management negotiation time and the potential demotivation from declining i-deals due to business reasons. Unfortunately, this simple intervention is not available to all teams, meaning that those employees that are unable to successfully articulate their request, are unlikely to benefit from an i-deal: 
.... she doesn't speak up for herself. ... but she was too, err, she couldn't communicate really. Have the confidence to say "can you give me a job in one of those [sites]?". So ..., when they asked her where she wanted to work, she said "anywhere." (Employee, 50-64 years, Nonprofessional Team 4)

Some denied i-deals appeared to create anger among staff suggesting psychological contract violation. For example, one denied i-deal involved a number of part-time nonprofessional employees having their hours changed from working two and a half days together, to working 5 days per week for a few hours per day as part of the organizational restructure. It was reported that this left employees feeling angry about having to work for a few hours every day, and they were unable to negotiate a flexibility i-deal to reverse it:

... they worked 18.5 hours a week, ..., they would work 2.5 days together. So either the beginning of the week or the end of the week. And they split that 18.5 hours, so that they had to come in every day at the busy periods over the week, and they were in uproar because they said "well we don't have a life outside of work then, we are in every day" ... some of those people had worked here for over 30 years, and they do not call in sick, they are reliable, err, they are loyal. (Employee, 50-64 years, Nonprofessional Team 4)

The employee that provided the aforementioned quote was not directly affected by that i-deal as a full-time member of staff. Nevertheless, the quote demonstrated the anger felt on behalf of the affected coworkers because their i-deal was denied. This suggests that denying an i-deal risks not only breaking the psychological contract of the employee requesting the $\mathrm{i}$-deal, but also reduces the organizational trust by coworkers if they feel that their coworker's i-deal should be approved. This also happened with another employee:

"And, instead of finding her, I mean, she had worked in the Council for over 30 years, she could do the job, errm, she was very good at her job, she would never phone in sick, cos it would have made her ill just to do that. She was never going to be late for work, she was never going to break a rule, she was $100 \%$ loyal.... instead of finding her another little [site] to go to, sort of like as a duty of care, they sent her here [i.e. largest and busiest site]!.” (Employee, 50-64 years, Nonprofessional Team 4)

Consequently, there was a perception here that the employee that had her redeployment i-deal denied was worthy of it given it was perceived that she had met her obligations to the organization by her hard work and loyalty over the years. That said, not all denied i-deals resulted in perceived psychological contract breach. For example, a career development i-deal was declined due to financial reasons for one of the nonprofessionals. The employee explained that the line manager advised:

[Management] couldn't pay for you to do a level 4, because you don't need [that] ... within this area. (Employee, 40-49 years, Nonprofessional Team 3)

The employee went on to explain:

I suppose it's like austerity as well, they can't really afford to let off the staff, we've not got enough staff to serve, so I do understand that, I know it's not just like them being like mean or what have you, they are looking at the bigger picture, whereas you know, I'm just looking out for myself. (Employee, 40-49 years, Nonprofessional Team 3)

Here, despite desiring external training, the employee recognizes that the organization cannot justify funding it and granting time off to attend college given the financial and staffing constraints within this frontline service (customer facing). This understanding may explain why it did not appear to breach the psychological contract or lead to 
disengagement. Given the possible impact on the psychological contract, the type of exchange fostered was then examined.

\section{3 | Type of exchange}

Flexibility i-deals appear to create a social exchange for some participants, and an economic exchange for others. For example, the flexibility i-deal reported earlier, which permitted a $50 \%$ reduction in hours and cost saving, seems to reflect a social exchange:

So it's about the relationship really-they get a [professional] manager for a half time salary, and I get half the time at home which is where I need to be-I have a family. (First-Line Manager, 50-64 years, Professional Team 1)

Here the First-Line Manager clearly recognizes the mutual benefits of the i-deal, but also the importance of a social long-term relationship too. Similarly, the flexibility i-deal where hours were agreed around the first-line manager's caring commitments also appears to demonstrate a social exchange:

I was willing to take on a full-time post, on the condition that it did not interfere [with home], which they were great about. ... Errm, and they have allowed me to fit my hours sort of around school day and stuff like that. So, it's been great. You know, I came up with my hours, they just said "yeah does it fit in?", "yeah," "that's fine."... It makes you feel wanted, not maybe wanted, appreciated. (Middle Manager, 40-49 years, Nonprofessional Team 4)

Here, the organization proposed the $\mathrm{i}$-deal in principle and allowed the i-deal recipient to consider how it could be achieved for mutual advantage. The relationship formed is demonstrated by the i-deal recipient's appreciation, and both parties focus on mutuality and trust. Whereas, one of the employees who had a similar flexibility i-deal suggests an economic exchange given the focus on the individual benefit received:

I work 4 days a week, 32 hours over 4 days, so I have 1 day off per week which is fantastic when you have family-errm, it gives you the quality of time that you need ..., it is just such a benefit. (Employee, 40-49 years, Professional Team 1)

Here, there was no reference to the employment relationship or any benefits to the organization or any openended agreements. Rather, this i-deal was described as a tangible employee benefit suggesting this singular focus makes it more transactional in nature. Consequently, as the same type of i-deal appeared to foster different types of exchange relationships, it may be that the attribution of why the i-deal was approved, rather than the content, is more important in determining whether a social or an economic exchange is fostered. The impact this may have on employee engagement will be discussed next.

As regards Research Question 2: Despite the dilution of the employment deal, managers and employees provided the following examples of engaged behavior.

\section{4 | Professional team 1}

Of particular interest is that Professional team 1 reported the most agreed i-deals (career development and flexibility i-deals), with no denied i-deals reported, and different management levels commented very favorably about employee engagement: 
I know they [employees] are engaged because they are keen to give ideas and feedback, errm, they make suggestions, and they propose new ways of working, errm, they are enthusiastic and errm, they offer help, errm they volunteer for things. (Middle Manager, 50-64 years, Professional Team 1)

... the quality of the reports that they do, the stuff that they have considered, the fact that they have taken care and sharing with colleagues before doing the reports and so on-there is no-one just sitting churning out the reports-there is no-one doing that. The three advisors ask each other, and share with each other ... (First-Line Manager, 50-64 years, Professional Team 1)

This demonstrates that line managers perceive employees to be cognitively and socially engaged when writing reports, ensuring they make the best recommendations by consulting with peers first, thinking, proposing, and sharing ideas and suggestions. Emotional and physical engagement is suggested by their apparent enthusiasm and willingness to volunteer. Given the professional nature of these roles, such behaviors are crucial. Furthermore, the innovativeness followed by social engagement to share, refine, and implement the innovations is essential for the Service to maintain delivery within the reduced funding. Working smarter rather than harder is key to sustaining engagement.

In addition, managers acknowledged that employees' cognitive engagement extends beyond their own job, and that they understand the austerity constraints and know how they are contributing to the organization's objectives:

... they [employees] understand the work that they are doing, and they understand the situation that we are in. (Senior Manager, age not declared, Professional Team 1)

\section{5 | Professional team 2}

This team had no agreed i-deals, and while management reported examples of their engagement, they did appear to consider that social engagement was lacking:

I think they work incredibly hard. ... But all of them, do things they do, because they want the best for our Service. (First-Line Manager, 40-49 years, Professional Team 2)

... that what I would hope would happen is that people are knocking on my door saying "I've got this great idea" or "I think we should be doing this." (Middle Manager A, 50-64 years, Professional Team 2)

Consequently, it appears that employees are engaged to the Service (suggesting either job, professional, organization, customer, team or line manager engagement, and potentially combinations of these different elements) and work hard. Despite that, innovations and suggestions for improvements do not appear to be forthcoming from this team. On exploring this with employees, they reported that they did not think it was appropriate to challenge management or try to improve the employment deal:

The trouble is, you are not meant to change somebody's policy, are you, I don't think. (Employee, 50-64 years, Professional Team 2)

I haven't really considered it [the employment deal] too much to be honest. You know, I am still in employment and employment is better than being unemployed. (Employee 3, 50-64 years, Professional Team 2)

This reluctance to use employee voice and challenge management may explain why i-deals are not requested, but also why Management considered them socially disengaged. Given the effort the employees make in other 
aspects of their work, it appears that something is preventing these hardworking employees from exercising creativity and employee voice, thus stifling development of the service.

\section{6 | Nonprofessional team 3}

As reported earlier, nonprofessional Team 3 had agreed redeployment i-deals. Their engagement examples included:

The Team really work well, they sound off each other. Yeah. And they will go and ask, rather than, if they think that I am busy, they'll go to a more experienced staff and say "well what do you think in this instance?" (First-Line Manager, 50-64 years, Nonprofessional Team 3)

But it [the redeployment i-deal] did make me work harder cos I felt as though I had to ..., the way I act with a customer, I'm just not representing myself, I'm representing [named LA]. And if I do a good job, the customer will see [named LA] as doing a good job. (Employee, 50-64 years, Nonprofessional Team 3)

This demonstrates effort along with focus on the job. When employees are unsure of the right course of action, they seek advice from more experienced coworkers thus maintaining ownership of the task while ensuring accuracy. Furthermore, the redeployment i-deal recipient demonstrates emotional engagement where they are as concerned for the organization's reputation as they are for their own, thus bringing their personal resources of belief, pride, and possibly knowledge to their work role.

\subsection{Nonprofessional team 4}

Nonprofessional Team 4 reported flexibility i-deals and behavioral engagement:

Even our Head of Service, [named], she sat me in here the other week, and she just said "you know you have done this, this, this and this, and it's all been brilliant, thanks, I really appreciate it, and I'm glad that you are in the post." And so, you know, I just think it is a brilliant place to work, I really do. (Middle-Line Manager/[now speaking in their employee role], 40-49 years, Nonprofessional Team 4)

Consequently, it appears that the Head of Service (indirect line manager) appreciates the efforts that the individual has made in their work, citing examples. In particular, her immediate line manager reflected the same positive comments about her behavioral engagement in relation to the effort (Kahn, 1990) and focus (Saks, 2006) the individual gave:

So she was doing all this work ... And she likes to get it finished. She wants to get the dots on the i's and the crosses on the t's. (Middle Manager, 40-49 years, Non Professional Team 4)

From these examples provided by line managers and employees, it appears that behavioral engagement is present among those that either have i-deals or understand the reasons for denial. These findings will be reflected on and discussed next.

\section{DISCUSSION}

The purpose of this article was to examine how i-deals (Rousseau, 2005) are used to help encourage acceptance of the changing psychological contract, in particular the demise of the public sector's notion of a "job for life" and reduced employment deal (CIPD/PPMA, 2012), and to foster employee engagement (Anand et al., 2010; Hornung 
et al., 2008; Rousseau, 2005; Vidyarthi et al., 2014). To achieve this, the use of i-deals will be discussed, followed by the impact on the psychological contract and employee engagement.

\section{1 | I-deals}

In line with Hornung et al.'s (2008) findings, i-deals were also present in this bureaucratic organization where standardized employment practices are prevalent. This may demonstrate the movement toward the individualization of the employment relationship, coupled with the austerity context creating the need to be leaner and more agile (Bach, 2011; CIPD/PPMA, 2012), herewith showing how macrochanges affect the microlevel. In fact, the willingness to discuss other coworkers' $\mathrm{i}$-deals both within the employee one-to-one interviews, and the open discussion of $\mathrm{i}$-deals in the employee interview focus groups, may suggest that individualized arrangements are the norm (Hornung et al., 2008). Given only $22 \%$ of the respondents reported on i-deals, rather, we assume that they openly discussed the i-deals because they were functional/transparent/fair (Rousseau et al., 2006). This strengthens the need for distributive, procedural, and interactional justice (Rousseau, 2005).

The low number of discussed i-deals also demonstrates their idiosyncratic nature. One explanation for this is that context limits i-deal success. Not only does the context have to provide i-deal availability (Anand et al., 2010; Hornung et al., 2008; Rosen et al., 2013; Rousseau, 2005; Rousseau et al., 2006), but employees requesting i-deals also need to have the preference/need for personal control (Wrzesniewski \& Dutton, 2001), self-efficacy, positive social interaction (Bandura, 1977; Hornung, Rousseau, Glaser, Angerer, \& Weigl, 2010), and confidence (Rousseau et al., 2006). The employee that failed to speak up for herself in Nonprofessional Team 4 case study demonstrated the consequences of this when these characteristics, preferences, and skills were lacking as it stifled both progress with the i-deal negotiation, and engagement in the new role. Low-cost interventions that help individuals present a business case, as shown by the "redeployment i-deal request form," enabled employees to articulate their request, suggesting it may be useful given that some staff may not have the business insight, negotiation skills, or self-belief that they can succeed in negotiation (Rousseau et al., 2006). This technique has been applied to suggestion schemes (Incomes Data Services, 2005) and may be more realistic in austerity than more costly interventions such as employee negotiation training.

\section{2 | I-deals and the psychological contract}

The categorization of i-deals into flexibility, employability/career development (task), and redeployment highlights the benefits that are important to these employees. The redeployment i-deals will be due to downsizing in response to austerity. In contrast to Kinnie, Hutchinson, Purcell, Rayton, and Swart's (2005) research, employability/career development needs were shown to be important to both professional and nonprofessional employees, perhaps reflecting the job insecurity making employability more important among employees with either an instrumental or career orientation to work (Goldthorpe et al., 1968). This may also demonstrate the acceptance of the new psychological contract (CIPD/PPMA, 2012; Hiltrop, 1995) where employees seek to enhance their employability through lower-cost workplace learning rather than expecting a "job for life" and/or external training. It also shows that i-deals are enabling employees to create learning paths driven by their own motives for learning (Poell, 2017). Furthermore, the transparent nature of $\mathrm{i}$-deals resulting from the negotiation and authorization processes may prevent some of the disadvantages that can come from informal learning, such as learning bad habits and/or negative attitudes (Billett, 1995; Dale \& Bell, 1999). It can also entail relevant on-the-job learning that formal learning may not be able to provide effectively (Cunningham \& Hillier, 2013; Hicks, Bagg, Doyle, \& Young, 2007). Such development may foster employee engagement (Shuck et al., 2014) by increasing Kahn's (1990) psychological meaningfulness (Fairlie, 2011). Managers only had flexibility i-deals within this small sample, perhaps because they have already met their (current) career aspirations. Here, Hornung et al.'s (2008) research was supported, where reduced hours did not 
lower the employer's performance expectations given the i-deal recipient had to convince management that the job could still be done.

Of further interest is that, while other studies have highlighted that i-deal benefits arise from the privileged status of gaining special terms and conditions not available to peers (e.g., Guerrero \& Challiol-Jeanblanc, 2016), this study demonstrated instances where peers felt that coworkers should be granted i-deals, especially in relation to redeployment and flexibility i-deals. Failure to grant them resulted in coworkers losing trust in the organization. This may be due to the transparent nature of public sector rewards demonstrating a further need to examine context in $\mathrm{i}$ deal studies (Rousseau, Hornung, \& Kim, 2009).

Although Rousseau et al. (2009) found that the type of exchange formed from an i-deal depends on the content of the i-deal, and that flexibility i-deals create an economic exchange, it was not shown in this study. Here, findings suggest that flexibility i-deals appeared to foster a social exchange for some participants, and an economic exchange for others. Consequently, it may be that the individual attribution of why the i-deal was approved may be more important than the content of the i-deal in determining the exchange relationship formed. The participant's acknowledgement of a social exchange relationship may also demonstrate a strong orientation to exchange (Cropanzano \& Mitchell, 2005).

To understand the quality of the social exchange between the line manager and employee, Foa's (1971) and Foa and Foa's $(1974,1976,1980,2012)$ resource theory is referred to in order to examine the types of resources exchanged (Gorgievski, Halbesleben, \& Bakker, 2011) and the reasons why. A resource is anything that can be transmitted from one person to another, including facial cues and body language (Foa \& Foa, 2012). Foa (1971) and Foa and Foa $(1974,1976,1980,2012)$ consider that resources may be classified into six types: money, goods, services, information, status, and love (termed affiliation by Wilson, Sin, \& Conlon, 2010). The resources are plotted against two axes consisting of, first, symbolic to concrete, which represents the extent of tangibility of the resource, and, second, universal to particularistic, which represents the extent to which the parties in the exchange affect the value of the specific resource (see Figure 1). The resource classes do overlap and are related, and represent meanings to actions (Foa \& Foa, 1976). This makes it useful for this study to understand theoretically how the reciprocations between line managers and employees are affected during times of austerity.

To apply this model, Hornung et al. (2008) stated that hard i-deals such as flexibility i-deals are concrete, objective, and measurable agreements (Bal, De Jong, Jansen, \& Bakker, 2012) and appear to reflect economic exchange

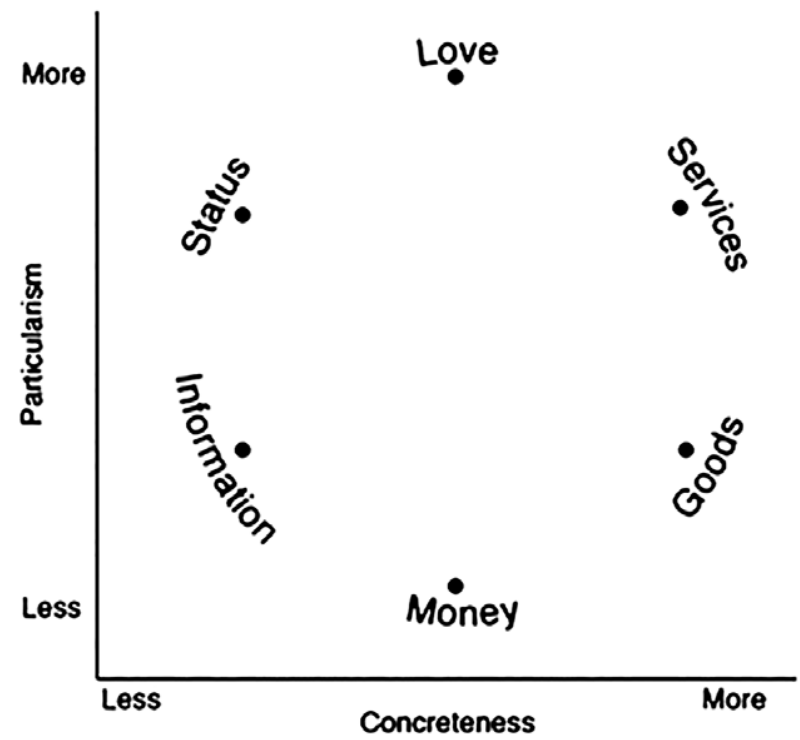

FIGURE 1 Resource theory. From Foa (1971). Reprinted with permission from AAAS 
(Rousseau et al., 2009). Soft i-deals such as developmental i-deals are more symbolic, subjective, and particularistic, and as such are more relational in nature, resulting in a social exchange (Bal et al., 2012).

Consequently, examining the i-deals in relation to Foa (1971) and Foa and Foa's (1974, 1976, 1980, 2012) resource theory seems to show that as the employment deal reduces (e.g., pay freeze, and reduction in benefits, terms and conditions, external training), these concrete, universal resources appear to be substituted with more particularistic resources (e.g., flexibility and career development/employability [task] i-deals). For example, although developmental $\mathrm{i}$-deals are considered soft, an external training course is more concrete and universal than the substituted career development/employability (task) i-deals, such as learning from project work or varied tasks that depend on the parties involved. Similarly, benefits, terms and conditions, which again are concrete and universal given they are collectively agreed, are being partially substituted by more particularistic resources such as flexibility ideals where the parties involved will agree the extent of flexibility for that individual.

This is of interest for two reasons. Firstly, it seems that as the employment deal reduces, rather than employees lowering their contribution to balance their exchange relationship (Van der Voet \& Vermeeren, 2016), some employees have actively sought alternative benefits to reshape their psychological contract. The intention to gain employability/career development (task) i-deals in particular may suggest acceptance of the new psychological contract by employees taking responsibility for their own development (Hiltrop, 1995). Secondly, it has already been highlighted that particularistic resources are informal ways of rewarding employees by adding particularistic nonmonetary rewards to the employment package (Rousseau et al., 2006). However, this study has found that this is happening to replace elements of the reward package as it reduces. While Foa and Foa $(1976,1980,2012)$ argue that when a resource is not available for exchange, it is more likely to be substituted by a less particularistic resource partly because it is easier to ask for, and because neighboring resources are more easily substituted than more distal ones, the opposite has happened in the case studies. This may be because the context is such that money (or monetary equivalent) is not available, so this leads to employees seeking out alternative resources to exchange for their engagement and to minimize the adverse effects of thwarting (Foa \& Foa, 1976; Wilson et al., 2010). However, it may also be that if a less particularistic resource is available to a satisfactory level (as shown by the employees being paid for their work), the shortfall (e.g., the equivalent of a pay rise, return to original benefits, terms and conditions, and formal off-the-job training) may be substituted by other more particularistic resources. That does not mean to say that such a strategy could be applied to all organizational contexts. As noted in the interview transcripts, employees in the case studies understood the national financial constraints that may have made them more accepting of the situation and search for low-cost alternative reciprocations. This again supports the need to examine context in future i-deals research (Rousseau et al., 2009). Nevertheless, it does show that even during austerity, the reciprocations between line managers and employees are still needed, demonstrating the line manager's role in shaping the psychological contract and fostering engagement through reciprocity.

That said, not all i-deals can be approved in the current austerity context. Given denied i-deals may disengage staff if they feel that their psychological contract has been breached/violated, it is in management's interests to adequately and respectfully explain the reasons for refusal. Understanding the reasons for denial may also provide a learning opportunity resulting in a more mutually beneficial future i-deal. Such action may maintain affective trust (which can continue after losing cognitive trust) to prevent psychological contract breach/violation (Atkinson, 2007; Robinson, 1996) and maintain engagement discussed next.

\section{3 | I-deals and employee engagement}

The impact of i-deals on Kahn's (1990) three psychological conditions may also explain how they foster engagement given i-deals can be tailored to favorably meet the dynamic subjective individual appraisal of work factors. For example, flexibility i-deals are likely to contribute toward psychological availability (Kahn, 1990) by supporting employees to gain more work-life balance thus enabling them to bring more personal energies to their role. Similarly, employability/career development (task) i-deals are likely to contribute to psychological meaningfulness (Kahn, 1990) via 
enhancing the work experience through meaning and purpose (Shuck \& Rose, 2013). Redeployment i-deals may contribute to psychological safety (Kahn, 1990) given these employees are likely to be concerned about their self-image, status, and career. Furthermore, Professional Team 2's reluctance to request i-deals or socially engage and be innovative may be indicative that psychological safety is lacking demonstrating the importance of fostering psychologically safe work climates (Kahn, 1990). Cognitively engaged employees are more likely to understand the business (MacLeod \& Clarke, 2009), which in turn makes them more likely to identify i-deals that are mutually advantageous suggesting that engagement drives i-deal negotiation. This innovation is necessary given cost cutting measures are insufficient to deal with the austerity constraints (Bach, 2011).

Rival explanations to explain employee engagement may be the employees' public sector commitment moderating their behaviors favorably toward the public despite perceived psychological contract breach (Conway et al., 2014). This may be providing resilience to employees, either in the form of engagement, or possibly "resigned acceptance" (Francis et al., 2013). Despite these rival explanations, the findings appear to show that there is engagement in the teams that have requested i-deals, although causality cannot be claimed in this qualitative cross-sectional study. It may be that the ability to request i-deals contributes to a work climate of psychological safety (Kahn, 1990) which may foster engagement.

In summary, previous research (Anand et al., 2010; Hornung et al., 2008; Vidyarthi et al., 2014) has shown that successful i-deal negotiation is more likely to foster employee contributions in reciprocation of such support. This study has extended this understanding to demonstrate that some employees seek alternative particularistic reciprocations in the form of $\mathrm{i}$-deals to replace the concrete, universal resources they have lost through budget cuts in the context of austerity, thus reshaping the psychological contract and fostering engagement. Although Foa and Foa $(1976,1980,2012)$ posit that resources are not normally substituted for more particularistic resources, the empirical case studies that are core in this scholarly work suggest that this happens when the universal resources are provided to a particular threshold. Consequently, while pay (universal) may not be substituted by i-deals (particularistic), small elements of pay such as inflationary pay rises (universal) may be replaced with i-deals (particularistic). This also highlights the importance of the line manager's role in fostering employee engagement (Alfes et al., 2010; Lewis et al., 2012) suggesting that reciprocity between line managers and employees matters. It may also demonstrate that engagement drives i-deal requests as engaged employees are more likely to identify i-deals with mutual benefits due to their knowledge of the business. Furthermore, the individual attribution of why the i-deal has been agreed may influence the exchange relationship formed more than the content of the i-deal. The transparent authorization process of developmental/task i-deals may also overcome some of the problems with workplace learning, such as learning bad habits/attitudes from others (Billett, 1995; Dale \& Bell, 1999), as well as providing relevant on-the-job learning that formal training cannot achieve (Cunningham \& Hillier, 2013; Hicks et al., 2007), and supporting employees in creating their own learning paths (Poell, 2017). Finally, it is in both the organization's and employees' interests if $\mathrm{i}$-deals are negotiated to a successful conclusion, or the reasons for denial are adequately explained to mitigate the risk of psychological contract breach/violation for employees, prevent loss of trust between coworkers and the organization, provide further learning, and respect employee voice.

\section{I IMPLICATIONS FOR HRD PRACTICE AND SCHOLARSHIP}

The fostering of engagement is an ongoing process (Shuck et al., 2012) so HRD practitioners should help managers and employees to foster and maintain engagement (Kim, Kolb, \& Kim, 2012). Fairlie (2011) has already suggested that HRD may do this by promoting development as a way of enhancing Kahn's (1990) psychological meaningfulness. These promotional efforts should include encouraging the use of developmental/task i-deals across the organization as a way of providing low-cost workplace learning for employees, rather than relying on employees taking the initiative to identify and prioritize learning activities (Choi \& Jacobs, 2011; Crouse et al., 2011; Lohman, 2006). This may be achieved by encouraging informal learning opportunities, emphasizing the line managers' role in facilitating 
learning (Jeon \& Kim, 2012), and developing the managerial skills to provide a climate where employees feel psychologically safe (Kahn, 1990) to exercise employee voice by negotiating i-deals and proposing innovations. Likewise, HRD practitioners will also need to support line managers in becoming sufficiently skilled in negotiating i-deals within their limited resources, and in positively explaining the reasons for denying i-deals to employees to prevent psychological contract breach/violation. A blended approach to this may achieve sustainability, for example, e-learning and face-to-face training to enhance line managers' knowledge and skills in negotiating and having difficult conversations, coupled with ongoing coaching to encourage self-reflection, transferring the learning to practice and fostering continuous improvement. Such action may mitigate the risk of psychological contract breach/violation, maintain organizational trust, provide further learning for the employee by understanding why their denied i-deal was inappropriate, which may lead to better future proposals and respect employee voice. An "i-deal request form" may help employees articulate their request if they lack the confidence/skills to negotiate and may enhance psychological safety (Kahn, 1990). It is also more cost effective in the austerity context compared to employee negotiation training.

In relation to HRD scholarship, this research has provided further support that SET (Blau, 1964) is a useful lens to understand $\mathrm{i}$-deals and understand how engagement may be fostered by line managers via demonstrating the importance of reciprocity. For example, it shows how HRD-related i-deals provide alternative low-cost developmental methods to enhance psychological meaningfulness (Kahn, 1990) when higher-cost learning methods such as external training are constrained. Furthermore, given the lack of academic agreement in relation to the employee engagement conceptualisation, and the number of engagement terms in use, we suggest using the term behavioral engagement where it is important to incorporate context and multiple voices in the study. Such an approach may make the link between HRD practice and engagement more explicit to aid assessment of outcomes to gain interest from multiple stakeholders (HRD scholars, practitioners, and practicing managers) thus facilitating the transfer of knowledge between academic and practitioner discourses (Cole et al., 2012; Lee, Kwon, Kim, \& Cho, 2016). This leads us to consider the limitations of this study and suggest areas for future research.

\section{7 | LIMITATIONS AND FUTURE RESEARCH}

The contribution of this article is to demonstrate empirically, through the lens of SET (Blau, 1964), how i-deals may be used in austerity to reshape the psychological contract and to foster employee engagement. This study has its limitations given that the understanding gained is constrained by the samples used (Rosen et al., 2013). Moreover, the cross-sectional nature means that it only shows associations rather than causality (Purcell \& Hutchinson, 2007), and that the findings are not generalizable to larger populations. There may be some gender/age bias given two thirds of the participant profile were either female or over 40 years of age. Furthermore, one of the researchers has prior LA experience and while this aids the understanding of context, it also provides a higher risk of bias. To reduce this and to contribute to qualitative rigor (Anderson, 2017), the study was conducted in a LA unknown to the researchers, findings were supported with interview quotes, and participants were encouraged to provide amendments to interview transcripts and/or to provide supplementary information (respondent validation-Guba \& Lincoln, 1994). Views on employee engagement were obtained from all levels of management and employees, which is superior to relying on employee self-report alone. However, to achieve this, this study examined behavioral engagement rather than psychological state engagement.

Further research could investigate quantitatively whether results are replicated across wider samples, and the longevity of i-deal effects by a longitudinal study. Watkins and Marsick (2014) have already suggested that more research is needed on how people are informally learning at work. It is proposed that this should include developmental/task i-deals together with a consideration of how learning effectiveness is (or could be) assessed, along with the impact on other outcomes such as employee satisfaction and commitment. Further exploring the link between ideals, engagement, and performance may be useful too (Fuller \& Shikaloff, 2017; Reijseger, Peeters, Taris, \& Schaufeli, 2017). It would also be interesting to investigate whether the formal i-deal authorization process reduces the 
likelihood of learning bad habits/attitudes from others (Billett, 1995; Dale \& Bell, 1999). So far, less attention has been paid to the role of frontline managers in facilitating learning (Cohen, 2013) and developmental/task i-deals may provide a useful way to explore this further. Examination of whether i-deals are more prominent during organizational change may also be worthwhile given the dependency on context. Exploring gender differences in pursuing ideals may also be of interest to highlight the resources desired by men and women, and the impact on their psychological availability and meaningfulness (Kahn, 1990). In addition, research to see if denied i-deals reflects issues of agency/structure (Heugens \& Lander, 2009), along with the impact on intrinsic motivation (Georgellis, lossa, \& Tabvuma, 2010), workplace trust (Battaglio \& Condrey, 2009), and justice are of interest, given the impact of managerial flexibility permitted by the i-deal agreement.

\section{CONCLUSION}

By examining i-deals through the lens of SET (Blau, 1964), this research demonstrates the role of reciprocity in the form of i-deals to accept the new psychological contract and to foster engagement. The study extends Foa and Foa's $(1976,1980,2012)$ resource theory by demonstrating how some employees seek alternative particularistic resources to make up the shortfall from constrained universal resources. In addition, resultant economic or social exchange may be due to the individual attribution of why the i-deal was agreed, rather than to the i-deal content. It may also suggest that engagement drives $\mathrm{i}$-deal requests as cognitively engaged employees with organizational knowledge are more likely to identify appropriate i-deals, which provide mutual benefits. Simple interventions that help employees articulate i-deal requests may enhance psychological safety (Kahn, 1990) and promote employee voice. The authorization process of $\mathrm{i}$-deals may also overcome some of the problems experienced with workplace learning such as learning bad habits/attitudes (Billett, 1995; Dale \& Bell, 1999). When i-deals are denied, action to lower the risk of psychological contract breach is advised. Consequently, this study has shown the reciprocations important to the sampled employees within the austerity context, providing some insight into the process of fostering engagement, which is likely to be of interest to practicing managers, HRD practitioners, and scholars. It is hoped that this may help move the debate of engagement to a more pluralist discourse (Bailey, Madden, Alfes, \& Fletcher, 2017) recognizing that even in austerity, reciprocity matters.

\section{ORCID}

Amanda S. Davis (D) https://orcid.org/0000-0002-1720-6529

\section{REFERENCES}

Alagaraja, M., \& Shuck, B. (2015). Exploring organizational alignment-employee engagement linkages and impact on individual performance: A conceptual model. Human Resource Development Review, 14, 17-37. https://doi.org/10. $1177 / 1534484314549455$

Alfes, K., Truss, C., Soane, E. C., Rees, C., \& Gatenby, M. (2010). Creating an engaged workforce: Findings from the Kingston Employee Engagement Consortium project. London, England: CIPD.

Amabile, T. M., \& Kramer, S. J. (2007). Inner work life - understanding the subtext of business performance. Harvard Business Review, 2007, 72-83.

Anand, S., Vidyarthi, P. R., Liden, R. C., \& Rousseau, D. M. (2010). Good citizens in poor-quality relationships: Idiosyncratic deals as a substitute for relationship quality. Academy of Management Journal, 53, 970-988. https://doi.org/10.5465/ amj.2010.54533176

Anderson, V. (2017). Criteria for evaluating qualitative research. Human Resource Development Quarterly, 28, 125-133. https://doi.org/10.1002/hrdq.21282

Argyris, C. (1960). Understanding organizational behavior. Homewood, IL: The Dorsey Press, Inc.

Atkinson, C. (2007). Trust and the psychological contract. Employee Relations, 29, 227-246. https://doi.org/10. 1108/01425450710741720

Bach, S. (2011). A new era of public service employment relations? The challenges ahead. Acas Future of Workplace Relations Discussion Paper Series, August 2011: London. 
Bailey, C., Madden, A., Alfes, K., \& Fletcher, L. (2017). The meaning, antecedents and outcomes of employee engagement: A narrative synthesis. International Journal of Management Reviews, 19, 31-53. https://doi.org/10.1111/ijmr.12077

Bakker, A. B. (2011). An evidence-based model of work engagement. Current Directions in Psychological Science, 20, 265-269. https://doi.org/10.1177/0963721411414534

Bal, P. M., De Jong, S. B., Jansen, P. G. W., \& Bakker, A. B. (2012). Motivating employees to work beyond retirement: A multi-level study of the role of i-deals and unit climate. Journal of Management Studies, 49, 306-331. https://doi. org/10.1111/j.1467-6486.2011.01026.x

Bal, P. M., \& Rousseau, D. M. (2016). Introduction to idiosyncratic deals between employees and organisations: Conceptual issues, applications and the role of co-workers. In P. M. Bal \& D. M. Rousseau (Eds.), Idiosyncratic deals between employees and organisations: Conceptual issues, applications and the role of co-workers (pp. 1-8). Oxon, England: Routledge.

Bandura, A. (1977). Self-efficacy: Toward a unifying theory of behavioural change. Psychological Review, 84, $191-215$.

Baron, A. (2013). What do engagement measures really mean? Strategic HR Review, 12, 21-25. https://doi.org/10. 1108/14754391311282450

Battaglio, R. P., Jr., \& Condrey, S. E. (2009). Reforming public management: Analyzing the impact of public service reform on organizational and managerial trust. Journal of Public Administration Research and Theory, 19, 689-707. https://doi. org/10.1093/jopart/mun030

Billett, S. (1995). Workplace learning: Its potential and limitations. Education and Training, 37(5), 20-27. https://doi.org/10. 1108/00400919510089103

Blaikie, N. (2007). Approaches to social enquiry (2nd ed.). Cambridge: Polity Press.

Blau, P. M. (1964). Exchange and power in social life. New Brunswick, Canada and London, England: Transaction Publishers.

Carey, M. A. (1994). The group effect in focus groups: Planning, implementing and interpreting focus group research. In J. M. Morse (Ed.), Critical issues in qualitative research methods (pp. 225-241). London, England: Sage.

Cepiku, D., Mussari, R., \& Giordano, F. (2016). Local governments managing austerity: Approaches, determinants and impact. Public Administration, 94, 223-243. https://doi.org/10.1111/padm.12222

Chell, E. (2004). Critical incident technique. In C. Cassell \& G. Symon (Eds.), Essential guide to qualitative methods in organizational research (pp. 45-60). London, England: Sage.

Choi, W., \& Jacobs, R. L. (2011). Influences of formal learning, personal learning orientation and supportive learning environment on informal learning. Human Resource Development Quarterly, 22, 239-257. https://doi.org/10.1002/hrdq.20078

CIPD in collaboration with PPMA. (2012). Leading culture change: Employee engagement and public service transformation. CIPD Policy into Practice.

Cohen, J. (2013). The nature of learning being facilitated by frontline managers. Human Resource Development International, 16, 502-518. https://doi.org/10.1080/13678868.2013.825143

Cole, M. S., Walter, F., Bedeian, A. G., \& O'Boyle, E. H. (2012). Job burnout and employee engagement: A meta-analytic examination of construct proliferation. Journal of Management, 38, 1550-1581. https://doi.org/10.1177/0149206311 415252

Conway, N., Kiefer, T., Hartley, J., \& Briner, R. B. (2014). Doing more with less? Employee reactions to psychological contract breach via target similarity or spillover during public sector organisational change. British Journal of Management, 25 , 737-754. https://doi.org/10.1111/1467-8551.12041

Coyle-Shapiro, J., \& Kessler, I. (2000). Consequences of the psychological contract for the employment relationship: A large scale survey. Journal of Management Studies, 37, 903-930. https://doi.org/10.1111/1467-6486.00210

Cropanzano, R., \& Mitchell, M. S. (2005). Social exchange theory: An interdisciplinary review. Journal of Management, 31, 874-900. https://doi.org/10.1177/0149206305279602

Crouse, P., Doyle, W., \& Young, J. D. (2011). Workplace learning strategies, barriers, facilitators and outcomes: A qualitative study among human resource management practitioners. Human Resource Development International, 14, 39-55. https:// doi.org/10.1080/13678868.2011.542897

Csikszentmihalyi, M. (1990). Flow: The psychology of optimal experience. New York, NY: Harper Perennial.

Cunningham, J., \& Hillier, E. (2013). Informal learning in the workplace: Key activities and processes. Education and Training, 55, 37-51. https://doi.org/10.1108/00400911311294960

Dale, M., \& Bell, J. (1999). Informal learning in the workplace, DFEE Research Brief 134. London, England: Department for Education and Employment.

Department for Business, Innovation \& Skills. (2011). New task force for employee engagement. London, England: Department for Business, Innovation \& Skills (replaced by the Department for Business, Energy \& Industrial Strategy Retrieved from http://www.bis.gov.uk/news/topstories/2011/Mar/employee-engagement-task-force

Eisenhardt, K. M. (1989). Building theories from case study research. Academy of Management Review, 14, 532-550. https:// doi.org/10.2307/258557

Fairlie, P. (2011). Meaningful work, employee engagement, and other key employee outcomes: Implications for human resource development. Advances in Developing Human Resources, 13, 508-525. https://doi.org/10.1177/1523422311 431679

Flanagan, J. C. (1954). The critical incident technique. Psychological Bulletin, 51(4), 327. 
Flyvbjerg, B. (2006). Five misunderstandings about case-study research. Qualitative Inquiry, 12, 219-245. https://doi.org/10. $1177 / 1077800405284363$

Foa, E. B., \& Foa, U. G. (1976). Resource theory of social exchange. In J. W. Thibaut, J. T. Spence, \& R. C. Carson (Eds.), Contemporary topics in social psychology (pp. 99-131). New Jersey: General Learning Press.

Foa, E. B., \& Foa, U. G. (1980). Resource theory: Interpersonal behaviour as exchange. In K. J. Gergen, M. S. Greenberg, \& R. H. Willis (Eds.), Social exchange: Advances in theory and research (pp. 77-94). New York, NY: Plenum Press.

Foa, E. B., \& Foa, U. G. (2012). Resource theory of social exchange. In K. Törnblom \& A. Kazemi (Eds.), Handbook of social resource theory: Theoretical extensions, empirical insights and social applications (pp. 15-32). New York, NY: Springer Science and Business Media.

Foa, U. G. (1971). Interpersonal and economic resources. Science, 171, 345-351. https://doi.org/10.1126/science.171. 3969.345

Foa, U. G., \& Foa, E. B. (1974). Societal structures of the mind. Illinois: Charles C Thomas.

Francis, H. M., Ramdhony, A., Reddington, M., \& Staines, H. (2013). Opening spaces for conversational practice: A conduit for effective engagement strategies and productive working arrangements. International Journal of Human Resource Management, 24, 2713-2740. https://doi.org/10.1080/09585192.2013.781530

Fredrickson, B. L. (2001). The role of positive emotions in positive psychology: The broaden-and-build theory of positive emotions. American Psychologist, 56(3), 218-226.

Fuller, R., \& Shikaloff, N. (2017). Being engaged at work is not the same as being productive. Harvard Business Review, 16, 2-5.

Georgellis, Y., lossa, E., \& Tabvuma, V. (2010). Crowding out intrinsic motivation in the public sector. Journal of Public Administration Research and Theory, 21, 473-493. https://doi.org/10.1093/jopart/muq073

Goldthorpe, J. H., Lockwood, D., Bechofer, F., \& Platt, J. (1968). The affluent worker: Industrial attitudes and behaviour. Cambridge, England: Cambridge University Press.

Gorgievski, M. J., Halbesleben, J. R. B., \& Bakker, A. B. (2011). Expanding the boundaries of psychological resource theories. Journal of Occupational and Organizational Psychology, 84, 1-7. https://doi.org/10.1111/j.2044-8325.2010.02015.x

Gouldner, A. W. (1960). The norm of reciprocity: A preliminary statement. American Sociological Review, 25, $161-178$. https://doi.org/10.2307/2092623

Gourlay, S., Alfes, K., Bull, E., Baron, A., Petrov, G., \& Georgellis, Y. (2012). Emotional or transactional engagement - does it matter? London, England: CIPD Research Insight May 2012.

Guba, E. G., \& Lincoln, Y. S. (1994). Competing paradigms in qualitative research. In N. K. Denzin \& Y. S. Lincoln (Eds.), Handbook of qualitative research (pp. 105-117). California: Sage.

Guerrero, S., \& Challiol-Jeanblanc, H. (2016). Idiosyncratic deals and helping behaviour: The moderating role of i-deal opportunity for co-workers. Journal of Business and Psychology, 31, 433-443. https://doi.org/10.1007/s10869-015-9421-x

Guest, D. E. (2014). Employee engagement: Fashionable fad or long-term fixture? In C. Truss, R. Delbridge, K. Alfes, A. Shantz, \& E. Soane (Eds.), Employee engagement in theory and practice (pp. 221-235). Oxon, England: Routledge.

Guest, D. E., \& Conway, N. (2002). Communicating the psychological contract: An employer perspective. Human Resource Management Journal, 12(2), 22-38. https://doi.org/10.1111/j.1748-8583.2002.tb00062.x

Heugens, P. P. M. A. R., \& Lander, M. W. (2009). Structure! Agency! (and other quarrels): A meta-analysis of institutional theories of organization. Academy of Management Journal, 52, 61-85. https://doi.org/10.5465/amj.2009.36461835

Hicks, E., Bagg, R., Doyle, W., \& Young, J. D. (2007). Canadian accountants: Examining workplace learning. Journal of Workplace Learning, 19, 61-77. https://doi.org/10.1108/13665620710728457

Hiltrop, J.-M. (1995). The changing psychological contract: The human resource challenge of the 1990s. European Management Journal, 13, 286-294. https://doi.org/10.1016/0263-2373(95)00019-H

HM Treasury. (2018). Spring statement 2018: Philip Hammond's speech. London, England: The Stationery Office Ltd Retrieved from https://www.gov.uk/government/speeches/spring-statement-2018-philip-hammonds-speech

Hornung, S., Rousseau, D. M., \& Glaser, J. (2008). Creating flexible work arrangements through idiosyncratic deals. Journal of Applied Psychology, 93, 655-664. https://doi.org/10.1037/0021-9010.93.3.655

Hornung, S., Rousseau, D. M., Glaser, J., Angerer, P., \& Weigl, M. (2010). Beyond top-down and bottom-up work redesign: Customizing job content through idiosyncratic deals. Journal of Organizational Behavior, 31, 187-215. https://doi.org/10. 1002/job.625

Incomes Data Services. (2005). Implementing a suggestion scheme, IDS HR Study 812, December 2005, 3-10. London, England: IDS.

Inman, P. (2018, March 14). UK will need to impose tax rises of $£ 30$ bn to balance budget - IFS. The Guardian Online, Retrieved from https://www.theguardian.com/business/2018/mar/14/uk-will-need-to-impose-tax-rises-of-30bn-tobalance-budget-says-ifs.

Janis, I. L. (1972). Victims of groupthink: A psychological study of foreign-policy decisions and fiascoes. Oxford, England: Houghton Mifflin Retrieved from http://psycnet.apa.org/index.cfm?fa=search.displayRecord\&uid=1975-29417-000

Jeon, K. S., \& Kim, K.-N. (2012). How do organisational and task factors influence informal learning in the workplace? Human Resource Development International, 15, 209-226. https://doi.org/10.1080/13678868.2011.647463. 
Kahn, W. A. (1990). Psychological conditions of personal engagement and disengagement at work. Academy of Management Journal, 33, 692-724. https://doi.org/10.5465/256287

Kahn, W. A. (1992). To be fully there: Psychological presence at work. Human Relations, 45, 321-349. https://doi.org/10. $1177 / 001872679204500402$

Kahn, W. A. (2010). The essence of engagement: Lessons from the field. In S. L. Albrecht (Ed.), Handbook of employee engagement: Perspectives, Issues, Research and Practice (pp. 20-30). Cheltenham: Edward Elgar Publishing Ltd.

Kahn, W. A., \& Heaphy, E. (2014). Relational contexts of personal engagement at work. In C. Truss, R. Delbridge, K. Alfes, A. Shantz, \& E. Soane (Eds.), Employee engagement in theory and practice (pp. 82-96). Oxon, England: Routledge.

Khilji, S. E., \& Wang, X. (2006). 'Intended' and 'implemented' HRM: The missing linchpin in strategic human resource management research. International Journal of Human Resource Management, 17, 1171-1189. https://doi.org/10.1080/ 09585190600756384

Kickert, W. (2012). State responses to the fiscal crisis in Britain, Germany and The Netherlands. Public Management Review, 14, 299-309. https://doi.org/10.1080/14719037.2011.637410

Kiefer, T., Hartley, J., Conway, N., \& Briner, R. B. (2014). Feeling the squeeze: Public employees' experiences of cutback and innovation-related organisational changes following a national announcement of budget reductions. Journal of Public Administration Research and Theory, 25(2014), 1279-1305. https://doi.org/10.1093/jopart/muu042

Kim, W., Kolb, J. A., \& Kim, T. (2012). The relationship between work engagement and performance: A review of empirical literature and a proposed research agenda. Human Resource Development Review, 12, 248-276. https://doi.org/10. $1177 / 1534484312461635$

King, D. (2012). Doing template analysis. In G. Symon \& C. Cassell (Eds.), Qualitative organisational research: Core methods and current challenges (pp. 426-450). London, England: Sage.

Kinnie, N., Hutchinson, S., Purcell, J., Rayton, B., \& Swart, J. (2005). Satisfaction with HR practices and commitment to the organisation: Why one size does not fit all. Human Resource Management Journal, 15(4), 9-29. https://doi.org/10.1111/j. 1748-8583.2005.tb00293.x

Lee, L., Kwon, K., Kim, W., \& Cho, D. (2016). Work engagement and career: Proposing research agendas through a review of literature. Human Resource Development Review, 15, 29-54. https://doi.org/10.1177/1534484316628356

Lewis, R., Donaldson-Feilder, E., \& Tharani, T. (2012). Managing for sustainable employee engagement: Developing a behavioural framework. London, England: CIPD.

Liao, C., Wayne, S. J., \& Rousseau, D. M. (2014). Idiosyncratic deals in contemporary organisations: A qualitative and meta-analytical review. Journal of Organizational Behavior, The IRIOP Annual Review Issue, 37, S9-S29. https://doi. $\operatorname{org} / 10.1002 /$ job.1959

Local Government Association. (2013). Redeployment and redundancy guide. London, England: Local Government Association.

Local Government Association. (2017). LGA budget submission Autumn 2017. London, England: Local Government Association Retrieved from https://www.local.gov.uk/sites/default/files/documents/5.20\%20budget\%20submission_06.pdf

Lohman, M. C. (2006). Factors influencing teachers' engagement in informal learning activities. Journal of Workplace Learning, 18, 141-156. https://doi.org/10.1108/13665620610654577

Macey, W. H., \& Schneider, B. (2008). The meaning of employee engagement. Industrial and Organizational Psychology, 1, 3-30. https://doi.org/10.1111/j.1754-9434.2007.0002.x

MacLeod, D., \& Clarke, N. (2009). Engaging for success: Enhancing performance through employee engagement. London, England: Department for Business Innovation \& skills (replaced by the Department for Business, Energy \& Industrial Strategy, Retrieved from http://www.bis.gov.uk/files/file52215.pdf.

Miles, M. B., Huberman, A. M., \& Saldaña, J. (2014). Qualitative data analysis - a methods sourcebook (3rd ed.). London, England: Sage.

Mintzberg, H. (1983). Structure in fives: Designing effective organisations. New Jersey: Prentice Hall.

Newman, D. A., \& Harrison, D. A. (2008). Been there, bottled that: Are state and behavioural work engagement new and useful construct "wines"? Industrial and Organizational Psychology, 1, 31-35. https://doi.org/10.1111/j.1754-9434.2007. 00003.x

Poell, R. E. (2017). Time to 'flip' the training transfer tradition: Employees create learning paths strategically. Human Resource Development Quarterly, 28, 9-15. https://doi.org/10.1002/hrdq.21279

Poppleton, S., Briner, R. B., \& Kiefer, T. (2008). The roles of context and everyday experience in understanding worknon-work relationships: A qualitative diary study of white and blue collar workers. Journal of Occupational and Organizational Psychology, 81, 481-502. https://doi.org/10.1348/096317908X295182

Purcell, J. (2012). The limits and possibilities of employee engagement. Warwick Papers in Industrial Relations Number 96. Coventry, England: University of Warwick, Industrial Relations Research Unit.

Purcell, J. (2014). Disengaging from engagement - provocation series paper. Human Resource Management Journal, 24 , 241-254. https://doi.org/10.1111/1748-8583.12046

Purcell, J., \& Hutchinson, S. (2007). Front-line managers as agents in the HRM-performance causal chain: Theory, analysis and evidence. Human Resource Management Journal, 17, 3-20. https://doi.org/10.1111/j.1748-8583.2007.00022.x 
Purcell, J., Kinnie, N., Hutchinson, S., Rayton, B., \& Swart, J. (2003). Understanding the people and performance link: Unlocking the black box. CIPD Research Report. London, England: Chartered Institute of Personnel and Development.

Reijseger, G., Peeters, M. C. W., Taris, T. W., \& Schaufeli, W. B. (2017). From motivation to activation: Why engaged workers are better performers. Journal of Business and Psychology, 32, 17-130. https://doi.org/10.1007/s10869-016-9435-z

Reissner, S., \& Pagan, V. (2013). Generating employee engagement in a public-private partnership: Management communication activities and employee experiences. International Journal of Human Resource Management, 24, 2741-2759. https:// doi.org/10.1080/09585192.2013.765497

Rich, B. L., Lepine, J. A., \& Crawford, E. R. (2010). Job engagement: Antecedents and effects on job performance. Academy of Management Journal, 53, 617-635. https://doi.org/10.5465/amj.2010.51468988

Robinson, S. L. (1996). Trust and breach of the psychological contract. Administrative Science Quarterly, 41, 574-599. https://doi.org/10.2307/2393868

Rosen, C. C., Slater, D. J., Chang, C.-H., \& Johnson, R. E. (2013). Let's make a deal: Development and validation of the ex post i-deals scale. Journal of Management, 39, 709-742. https://doi.org/10.1177/0149206310394865

Rousseau, D. M. (1989). Psychological and implied contracts in organisations. Employee Responsibilities and Rights Journal, 2, 121-139. https://doi.org/10.1007/BF01384942

Rousseau, D. M. (2005). I-deals: Idiosyncratic deals employees bargain for themselves. New York, NY: ME Sharpe.

Rousseau, D. M., Ho, V. T., \& Greenberg, J. (2006). I-deals: Idiosyncratic terms in employment relationships. The Academy of Management Review, 31, 977-994. https://doi.org/10.2307/20159261

Rousseau, D. M., Hornung, S., \& Kim, T. G. (2009). Idiosyncratic deals: Testing propositions on timing, content, and the employment relationship. Journal of Vocational Behavior, 74, 338-348. https://doi.org/10.1016/j.jvb.2009.02.004

Saks, A. M. (2006). Antecedents and consequences of employee engagement. Journal of Managerial Psychology, 21, 600-619. https://doi.org/10.1108/02683940610690169

Saks, A. M. (2008). The meaning and bleeding of employee engagement: How muddy is the water. Industrial and Organizational Psychology, 1, 40-43. https://doi.org/10.1111/j.1754-9434.2007.00005.x

Saks, A. M., \& Gruman, J. A. (2014). What do we really know about employee engagement? Human Resource Development Quarterly, 25, 155-182. https://doi.org/10.1002/hrdq.21187

Schaufeli, W. B. (2014). What is engagement? In C. Truss, R. Delbridge, K. Alfes, A. Shantz, \& E. Soane (Eds.), Employee engagement in theory and practice (pp. 15-35). Oxon, England: Routledge.

Schaufeli, W. B., Salanova, M., González-Romá, V., \& Bakker, A. B. (2002). The measurement of engagement and burnout: A two sample confirmatory factor analytic approach. Journal of Happiness Studies, 3, 71-92. https://doi.org/10.1023/A: 1015630930326

Schein, E. H. (1980). Organisational psychology (3rd ed.). Englewood, NJ: Prentice Hall Inc.

Shuck, B., Ghosh, R., Zigarmi, D., \& Nimon, K. (2012). The jingle jangle of employee engagement: Further exploration of the emerging construct and implications for workplace learning and performance. Human Resource Development Review, 12 , 1-35. https://doi.org/10.1177/1534484312463921

Shuck, B., \& Herd, A. M. (2012). Employee engagement and leadership: Exploring the convergence of two frameworks and implications for leadership development in HRD. Human Resource Development Review, 11, 156-181. https://doi.org/10. $1177 / 1534484312438211$

Shuck, B., Osam, K., Zigarmi, D., \& Nimon, K. (2017). Definitional and conceptual muddling: Identifying the positionality of employee engagement and defining the construct. Human Resource Development Review, 16, 263-293. https://doi. org/10.1177/1534484317720622

Shuck, B., \& Reio, T. G., Jr. (2011). The employee engagement landscape and HRD: How do we link theory and scholarship to current practice? Advances in Developing Human Resources, 13, 419-428. https://doi.org/10.1177/1523422311 431153

Shuck, B., Rocco, T. S., \& Albornoz, C. A. (2011). Exploring employee engagement from the employee perspective: Implications for HRD. Journal of European Industrial Training, 35, 300-325. https://doi.org/10.1108/03090591111128306

Shuck, B., \& Rose, K. (2013). Reframing employee engagement within the context of meaning and purpose: Implications for HRD. Advances in Developing Human Resources, 15, 341-355. https://doi.org/10.1177/1523422313503235

Shuck, B., Twyford, D., Reio, T. G., Jr., \& Shuck, A. (2014). Human resource development practices and employee engagement: Examining the connection with employee turnover intentions. Human Resource Development Quarterly, 25 , 239-270. https://doi.org/10.1002/hrdq.21190

Shuck, B., \& Wollard, K. (2010). Employee engagement and HRD: A seminal review of the foundations. Human Resource Development Review, 9, 89-110. https://doi.org/10.1177/1534484309353560

Soane, E., Truss, C., Alfes, K., Shantz, A., Rees, C., \& Gatenby, M. (2012). Development and application of a new measure of employee engagement: The ISA engagement scale. Human Resource Development International, 15, 529-547. https://doi. $\operatorname{org} / 10.1080 / 13678868.2012 .726542$

Tracy, S. J. (2010). Qualitative quality: Eight "big-tent" criteria for excellent qualitative research. Qualitative Inquiry, 16, 1-15. https://doi.org/10.1177/1077800410383121 
Truss, C., Shantz, A., Soane, E., Alfes, K., \& Delbridge, R. (2013). Employee engagement, organisational performance and individual well-being: Exploring the evidence, developing the theory. International Journal of Human Resource Management, 24, 2657-2669. https://doi.org/10.1080/09585192.2013.798921

Truss, K. (2014). The future of research in employee engagement. In D. Robinson \& J. Gifford (Eds.), The future of engagement tough piece collection, engage for success peer-reviewed thought leadership series (pp. 80-87). London, England: IES (Institute for Employment Studies).

Unison. (2018). Unison accepts local government pay offer. London, England: Unison Retrieved from https://www.unison.org. uk/news/article/2018/04/unison-accepts-local-government-pay-offer/

Valentine, S., Hollingworth, D., \& Francis, C. A. (2013). Quality-related HR practices, organizational ethics, and positive work attitudes: Implications for HRD. Human Resource Development Quarterly, 24, 493-523 doi: 10/1002/hrdq.21169.

Van der Voet, J., \& Vermeeren, B. (2016). Change management in hard times: Can change management mitigate the negative relationship between cutbacks and the organizational commitment and work engagement of public sector employees? The American Review of Public Administration, 47, 230-252. https://doi.org/10.1177/0275074015625828

Vidyarthi, P. R., Chaudhry, A., Anand, S., \& Liden, R. C. (2014). Flexibility i-deals: How much is ideal? Journal of Managerial Psychology, 29, 246-265. https://doi.org/10.1108/JMP-07-2012-0225

Watkins, K. E., \& Marsick, V. J. (2014). Developing individual and organizational learning capacity. Human Resource Development Quarterly, 25, 10-14. https://doi.org/10.1002/hrdq.21180

Wilkinson, A. (2005). Downsizing, rightsizing or dumbsizing: Quality, human resources and the management of sustainability. Total Quality Management and Business Excellence, 16, 1079-1088 doi: 10.1080=14783360500163326.

Wilson, K. S., Sin, H.-P., \& Conlon, D. E. (2010). What about the leader in the leader-member exchange? The impact of resource exchanges and substitutability on the leader. Academy of Management Review, 35, 358-372. https://doi.org/10. 5465/amr.35.3.zok358

Wrzesniewski, A., \& Dutton, J. E. (2001). Crafting a job: Revisioning employees as active crafters of their work. Academy of Management Review, 26, 179-201. https://doi.org/10.5465/amr.2001.4378011

Yin, R. K. (2009). Case study research - design and methods (4th ed.). London, England: Sage.

\section{AUTHOR'S BIOGRAPHIES}

Amanda S. Davis is a doctoral candidate at Manchester Metropolitan University in the UK. Amanda previously worked in two local authorities for 20 years, including over 10 years in middle management positions and OD (Organisational Development) consultancy. This research was purposefully conducted in another local authority which is outside of the local area to reduce researcher bias. Amanda now lectures on Human Resource Management, Leadership and Management.

Prof. Beatrice I.J.M. Van der Heijden, PhD is professor of Strategic HRM at the Radboud University, Institute for Management Research, Nijmegen, the Netherlands, and Head of the Department Strategic HRM. Moreover, she occupies a Chair in Strategic HRM at the Open University of the Netherlands, at Kingston University, London, UK, and at Hubei University, Wuhan, China. Her main research areas are: career development, employability, and aging at work. Van der Heijden is Associate Editor for the European Journal of Work and Organizational Psychology and Co-Editor for the German Journal of Human Resource Management, and has published, among others in the European Journal of Work and Organizational Psychology, Journal of Vocational Behavior, HRM, Journal of Occupational and Organizational Psychology, and Career Development International. She is coeditor of the Handbook of Research on Sustainable Careers (EE Publishing).

How to cite this article: Davis AS, Van der Heijden BIJM. Reciprocity matters: Idiosyncratic deals to shape the psychological contract and foster employee engagement in times of austerity. Human Resource Development Quarterly. 2018;29:329-355. https://doi.org/10.1002/hrdq.21327 


\section{APPENDIX A}

Sample size

\begin{tabular}{|c|c|c|c|c|c|c|c|}
\hline Team/case study & $\begin{array}{l}\text { Line } \\
\text { managers }\end{array}$ & $\begin{array}{l}\text { Employees one- } \\
\text { to-one interviews }\end{array}$ & $\begin{array}{l}\text { Employees focus } \\
\text { group interviews }\end{array}$ & $\begin{array}{l}\text { Total } \\
\text { employees }\end{array}$ & $\begin{array}{l}\text { Total } \\
\text { participants }\end{array}$ & $\begin{array}{l}\text { Total team } \\
\text { headcount }\end{array}$ & $\begin{array}{l}\text { Percentage } \\
\text { sampled }\end{array}$ \\
\hline Professional 1 & 3 & 0 & 5 & 5 & 8 & 63 & 13 \\
\hline Professional 2 & 4 & 3 & 0 & 3 & 7 & 10 & 70 \\
\hline Nonprofessional 3 & 4 & 5 & $6+5=11$ & 16 & 20 & 34 & 59 \\
\hline Nonprofessional 4 & 2 & 8 & 0 & 8 & 10 & 25 & 40 \\
\hline Total & 13 & 16 & 16 & 32 & 45 & 132 & 34 \\
\hline
\end{tabular}

Profile of participants

\begin{tabular}{|c|c|c|c|c|c|c|c|c|}
\hline Team 1-Professional & Age & & Gend & & $\begin{array}{l}\text { Service with } \\
\text { this LA (yrs) }\end{array}$ & $\begin{array}{l}\text { LA } \\
\text { service } \\
\text { (yrs) }\end{array}$ & Highest level qualification & $\begin{array}{l}\text { Interview } \\
\text { method }\end{array}$ \\
\hline Senior manager & Not decl & ared & $\mathrm{F}$ & & 3 & 3 & Not declared & One-to-one \\
\hline Middle manager & $50-64$ & & $\mathrm{~F}$ & & 9 & 9 & Masters degree & One-to-one \\
\hline First-line manager & $50-64$ & & M & & 7 & 7 & Professional qualifications & One-to-one \\
\hline Employee 1 & $40-49$ & & $\mathrm{~F}$ & & 3 & 3 & Masters degree & Focus group \\
\hline Employee 2 & $40-49$ & & $\mathrm{~F}$ & & 8 & 8 & Professional qualifications & Focus group \\
\hline Employee 3 & $40-49$ & & $\mathrm{~F}$ & & 12 & 12 & Undergraduate degree & Focus group \\
\hline Employee 4 & $40-49$ & & $\mathrm{~F}$ & & 5 & 23 & Professional qualifications & Focus group \\
\hline Employee 5 & $25-39$ & & $\mathrm{~F}$ & & 9 & 9 & Professional qualifications & Focus group \\
\hline Team 2-Professional & Age & \multicolumn{2}{|c|}{ Gender } & & $\begin{array}{l}\text { rvice with } \\
\text { is LA (yrs) }\end{array}$ & $\begin{array}{l}\text { LA } \\
\text { service (yrs) }\end{array}$ & $\begin{array}{l}\text { Highest level } \\
\text { qualification }\end{array}$ & $\begin{array}{l}\text { Interview } \\
\text { method }\end{array}$ \\
\hline Senior manager & $50-64$ & \multicolumn{2}{|l|}{ M } & 33 & & 33 & Professional qualifications & One-to-one \\
\hline Middle manager $\mathrm{A}^{\mathrm{a}}$ & $50-64$ & \multicolumn{2}{|l|}{$\mathrm{F}$} & 33 & & 33 & Masters degree & One-to-one \\
\hline Middle manager $\mathrm{B}^{\mathrm{a}}$ & $50-64$ & \multicolumn{2}{|l|}{$\mathrm{F}$} & 38 & & 38 & Undergraduate degree & One-to-one \\
\hline $\begin{array}{l}\text { First-line manager in team } \\
2 \& \text { middle manager in } \\
\text { team } 4\end{array}$ & $40-49$ & \multicolumn{2}{|l|}{$\mathrm{F}$} & 24 & & 24 & Masters degree & One-to-one \\
\hline Employee 1 & $50-64$ & \multicolumn{2}{|l|}{ M } & 45 & & 45 & Undergraduate degree & One-to-one \\
\hline Employee 2 & $50-64$ & \multicolumn{2}{|l|}{ M } & 40 & & 41 & Professional qualifications & One-to-one \\
\hline Employee 3 & $50-64$ & \multicolumn{2}{|l|}{$\mathrm{F}$} & 19 & & 19 & Professional qualifications & One-to-one \\
\hline
\end{tabular}

\begin{tabular}{lllllll}
\hline Team 3-Nonprofessional & Age & Gender & $\begin{array}{l}\text { Service with } \\
\text { this LA (yrs) }\end{array}$ & $\begin{array}{l}\text { LA } \\
\text { service (yrs) }\end{array}$ & $\begin{array}{l}\text { Highest level } \\
\text { qualification }\end{array}$ & $\begin{array}{l}\text { Interview } \\
\text { method }\end{array}$ \\
\hline Senior manager & $40-49$ & $\mathrm{~F}$ & 30 & 30 & Masters degree & One-to-one \\
\hline Middle manager & $40-49$ & $\mathrm{M}$ & 25 & 25 & Level 4 & One-to-one \\
\hline First-line manager & $40-49$ & $\mathrm{~F}$ & 18 & 18 & Masters degree & One-to-one \\
\hline First-line manager & $50-64$ & $\mathrm{~F}$ & 33 & 33 & NVQ 3 & One-to-one \\
\hline Employee 1 & $40-49$ & $\mathrm{~F}$ & 2 & 2 & Level 3 & One-to-one \\
\hline Employee 2 & $16-24$ & $\mathrm{~F}$ & 3 & 3 & Level 2 & One-to-one \\
\hline Employee 3 & $50-64$ & $\mathrm{M}$ & 33 & 33 & Level 4 & One-to-one \\
\hline
\end{tabular}




\begin{tabular}{|lllllll|}
\hline Team 3-Nonprofessional & Age & Gender & $\begin{array}{l}\text { Service with } \\
\text { this LA (yrs) }\end{array}$ & $\begin{array}{l}\text { LA } \\
\text { service (yrs) }\end{array}$ & $\begin{array}{l}\text { Highest level } \\
\text { qualification }\end{array}$ & $\begin{array}{l}\text { Interview } \\
\text { method }\end{array}$ \\
\hline Employee 4 & $40-49$ & $\mathrm{M}$ & 3 & 3 & Level 2 & One-to-one \\
\hline Employee 5 & $40-49$ & $\mathrm{M}$ & 7 & 7 & Level 4 & One-to-one \\
\hline Employee 6 & $50-64$ & $\mathrm{M}$ & 8 & 8 & Level 4 & Focus group 1 \\
\hline Employee 7 & $40-49$ & $\mathrm{~F}$ & 19 & 19 & Level 3 & Focus group 1 \\
\hline Employee 8 & $40-49$ & $\mathrm{~F}$ & 13 & 13 & Undergraduate & Focus group 1 \\
\hline Employee 9 & $40-49$ & $\mathrm{M}$ & 5.5 & 5.5 & degree & Level 3 \\
\hline Employee 10 & $50-64$ & $\mathrm{~F}$ & 15 & 15 & Level 3 & Focus group 1 \\
\hline Employee 11 & $50-64$ & $\mathrm{~F}$ & 12 & 12 & Level 3 & Focus group 1 \\
\hline Employee 12 & $25-39$ & $\mathrm{~F}$ & 16 & 16 & Level 3 & Focus group 2 \\
\hline Employee 13 & $50-64$ & $\mathrm{~F}$ & 18 & 18 & Level 2 & Focus group 2 \\
\hline Employee 14 & $25-39$ & $\mathrm{M}$ & 4 & 4 & Level 3 & Focus group 2 \\
\hline Employee 15 & $16-24$ & $\mathrm{~F}$ & 4.5 & 4.5 & Level 3 & Focus group 2 \\
\hline Employee 16 & $16-24$ & $\mathrm{M}$ & 1 & 1 & & \\
\hline
\end{tabular}

\begin{tabular}{lllllll}
\hline Team 4-Nonprofessional & Age & Gender & $\begin{array}{l}\text { Service with } \\
\text { this LA (yrs) }\end{array}$ & $\begin{array}{l}\text { LA } \\
\text { service (yrs) }\end{array}$ & $\begin{array}{l}\text { Highest level } \\
\text { qualification }\end{array}$ & $\begin{array}{l}\text { Interview } \\
\text { method }\end{array}$ \\
\hline Middle manager & $40-49$ & $\mathrm{~F}$ & 26 & 26 & Level 4 & One-to-one \\
\hline First-line manager & $16-24$ & $\mathrm{~F}$ & 6.5 & 6.5 & Level 3 & One-to-one \\
\hline Employee 1 & $50-64$ & $\mathrm{~F}$ & 14 & 14 & Level 3 & One-to-one \\
\hline Employee 2 & $16-24$ & $\mathrm{~F}$ & 5 & 5 & Level 2 & One-to-one \\
\hline Employee 3 & $25-39$ & $\mathrm{~F}$ & 3 & 3 & Lndergraduate & One-to-one \\
\hline Employee 4 & $16-24$ & $\mathrm{~F}$ & 8 & 8 & Level 3 & One-to-one \\
\hline Employee 5 & $50-64$ & $\mathrm{~F}$ & 36 & 36 & Level 2 & One-to-one \\
\hline Employee 6 & $16-24$ & $\mathrm{M}$ & 6 & 6 & Level 3 & One-to-one \\
\hline Employee 7 & $50-64$ & $\mathrm{~F}$ & 35 & 35 & Level 2 & One-to-one \\
\hline Employee 8 & $50-64$ & $\mathrm{~F}$ & 32 & 32 & & One-to-one \\
\hline
\end{tabular}

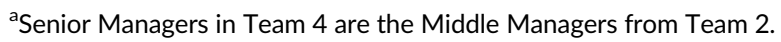

